
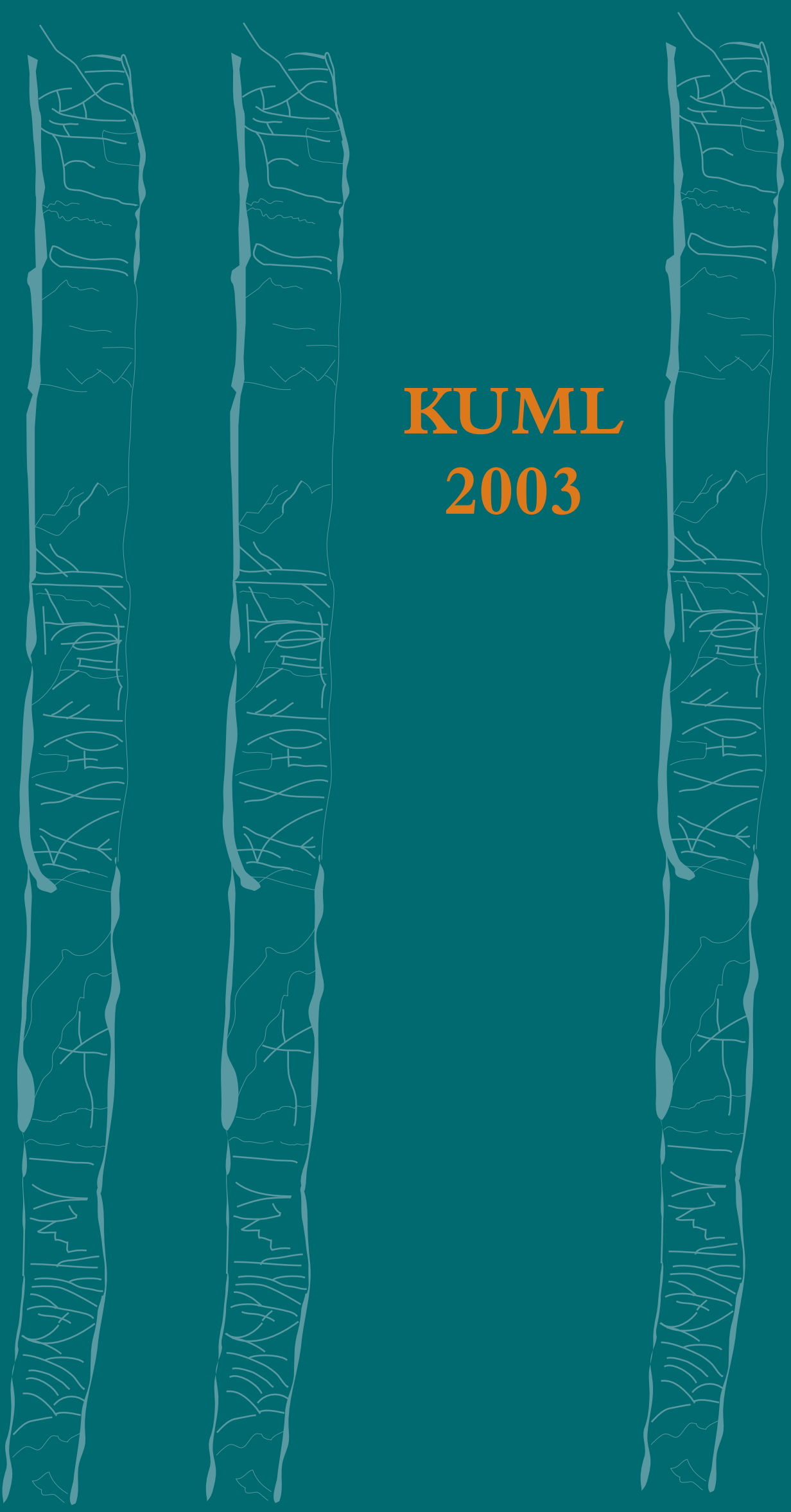


\section{KUML 2003}

Årbog for Jysk Arkæologisk Selskab

With summaries in English

I kommission hos Aarhus Universitetsforlag 


\section{Det Historiske Museum i Århus}

- gennem 100 år

Af JENS B. SKRIVER

At samle på ting kan betragtes som en almen menneskelig foreteelse. Fyrster, kirker og klostre har gennem tiderne haft samlinger af meget forskellig art, som umiddelbart kunne kaldes rariteter. ${ }^{1}$ Det er imidlertid nærliggende at se på de dybereliggende årsager til, at museumstanken med Oplysningstiden og ikke mindst Den franske Revolution bredte sig over hele Europa. Der blev da også i Danmark indrettet offentlige samlinger med det formål at opbevare særlige genstande, der skulle bevares for eftertiden, og sandelig ikke mindst at formidle disses budskab videre. Rødderne gik tilbage til 1700-tallets Italien, hvor barokarkitekterne var begyndt at opmåle antikke bygningslevn, og systematiske arkæologiske udgravninger blev påbegyndt. Inden for stilhistorien kendetegnes det ved den retning, som kaldes klassicismen, der søgte at efterligne de klassiske forbilleder så nøje som muligt. Restaureringer skulle foretages så nænsomt, det kunne lade sig gøre, og i det hele taget blev tilstræbt en synlig kontakt med fortiden. Ideen med indretning af offentlige museer var derved nærliggende. Disse strømninger kom til at smelte sammen med de nationale og borgerlige bevægelser. Den opfattelse trådte gradvis igennem, at et lands indbyggere ikke blot var undersåtter, men statsborgere. Staten var til for deres skyld og skulle sikre dem grundlæggende rettigheder. Til gengæld påhvilede der den fædrelandskærlige borger et ansvar, da helhedens trivsel afhang af hans driftighed og moral. I stedet for den passive lydighed var det nu det loyale, aktive borgersind, som blev idealet. ${ }^{2}$ Befolkningen skulle formes til ansvarsbevidste borgere gennem opdragelse og dannelse. ${ }^{3}$ Det kunne fælles minder om fortiden hjælpe med til. Følelse af fælles identitet kunne skabes ved forestillinger om en fælles glorværdig fortid. I Nordeuropa konkurrerede antikke forbilleder længe med de oldnordisk/germanske. I Danmark tippede vægten over til sidstnævnte med kunsthistorikeren N.L. Høyens indsats i 1840'erne.

Det kgl. Museum for de nordiske Oldsager var blevet indrettet i København 1807. Umiddelbar baggrund herfor var bl.a., at flere og flere oldsager gik til grunde. ${ }^{4}$ Snart blev Christian Jürgensen Thomsen (1788-1865) museets chef. Under hans ledelse fungerede museet som en videnskabelig smeltedigel,${ }^{5}$ hvor videnskabelige landvindinger som tre-periode-delingen 
blev skabt under det daglige arbejde med systematisering af genstandene under skyldig hensyntagen til de ideer og teorier, der kendetegnede tiden. ${ }^{6}$ Samtidig blev der lagt mange kræfter i omvisning af besøgende.

Oldnordisk Museum fik snart en filial i Kiel, og 1852-64 var Den kongelige Samling af nordiske Oldsager i Flensborg stillet til rådighed for det offentlige. Den var efter den tids forhold meget omfattende og fik meget store bevillinger. ${ }^{7}$

I 1850'erne og 1860'erne oprettedes de første provinsmuseer i kongeriget. De red ikke kun på den almindelige museumsbølge. Bag oprettelsen lå også mere politiske undertoner. Provinsmuseerne var således led i et opgør med Københavns dominans. Enevælden havde været kendetegnet ved, at hoffet, militæret og centraladministrationen var samlet i København, hvorved byen var blevet voldsomt overdimensioneret i forhold til det øvrige land. ${ }^{8}$ Ligeledes var provinsmuseernes oprettelse led i liberalismens opgør med statsmagtens dominans. ${ }^{9}$

\section{Etablering af museet $\mathrm{i}$ Århus}

Forløberne herfor var en kunstforening, stiftet i $1847,{ }^{10}$ og Historisk-antikvarisk Selskab, stiftet 19. marts 1861. Sidstnævnte indebar grundlæggelsen af et historisk museum i Århus. I det følgende skal dets historie i de næste hundrede år skrives. Dets historie afveg på væsentlige punkter fra andre provinsmuseers. Det var ikke en enkelt mand eller families værk, men resultatet af vidt forskellige kompetente kræfters indsats til forskellige tider. Dets udvikling var også kendetegnet af stagnation i perioder, hvor andre provinsmuseer ekspanderede.

Store dele af museets arkiv er bevaret på Moesgård Museum. Udnyttelsen af materialet kan være lumsk. Ikke alene kan der være reelle huller i det, der er bevaret, men de involverede mødtes hyppigt og har ofte truffet mundtlige aftaler. Der var ikke det samme behov for at skrive sammen, som hvis de havde opholdt sig i forskellige byer. Til gengæld indeholder arkivet mange koncepter til breve til modtagere rundt om i landet, så talrige sager kan belyses ved brug af dette arkiv alene.

\section{Grundlaggelsen}

Kunstmuseet havde i 1856 fået tilladelse til at benytte to lokaler på loftet af det nyopførte rådhus nord for Domkirken. Selv om der var få direkte personsammenfald, var det de samme kredse fra byens højere borgerskab, der både stod bag kunstmuseet og den lidt yngre historiske samling.

Efter forskellige sonderinger nedsattes en foreløbig bestyrelse for et historisk-antikvarisk selskab, og der indkaldtes til et foreløbigt møde i 
rådhussalen 29. januar $1861 .{ }^{11}$ Omkring 80 fremtrædende borgere fra byen og egnen tegnede selskabet, og der kunne indkaldes til en stiftende generalforsamling. På den egentlige stiftelse i marts 1861 blev selskabets vedtægter stadfæstede, og bestyrelsen valgt. Foreningens navn blev HistoriskAntikvarisk Selskab. ${ }^{12}$

I vedtægterne blev slået fast, at selskabet havde til formål at fremme sansen for mindesmærker fra ældre tid, især danske. Det skulle ske dels ved anlæggelsen af en historisk-antikvarisk samling i Århus og dels ved afholdelse af foredrag og fremvisninger af samlingen.

Egentlig var der tale om en privat forening, hvor medlemmerne skulle betale et årligt kontingent på 2 rigsdaler, men selskabets almennyttige karakter understreges i bestemmelserne om selskabets eventuelle opløsning. I så fald skulle samlingerne tilfalde Århus by og amt. Selskabet blev da også nogle år senere (1873) optaget i Hof- og Statskalenderen, og Frederik VII og derefter Christian IX var protektorer.

\section{En øjenvidneskildring}

Det er baggrunden for, at man ved juletid 1861 kunne læse følgende i Århus Stiftstidende skrevet af et anonymt øjenvidne:

"De kjøbenhavnske Samlinger frembyder imidlertid en Ulempe, idet Provindsernes Beboere kun leilighedsvis kunne faa dem at see, og Provindsbeboerene er derfor i dette som i mange andre Forhold Stifbørn (stedbørn) i Sammenligning med Kjøbenhavnerne. Det er naturligvis ikke min Mening med disse Ord at ville antyde, at Kjøbenhavn ikke skulle have sine store og fortrinlige Samlinger, eller at Provindsbeboerne skulle se skævt til dem«. »... Min Mening er kun den, at der ogsaa i Landets større Kiøbstæder baade kan og bør gjøres Noget for at fremme Folkeopdragelsen. At der virkelig kan gjøres Noget i denne Retning, fik jeg Beviis for ved mit Besøg i Aarhus.

Da jeg havde erfaret, at der paa Byens Raadhus findes et par Samlinger, som ere offentlig tilgængelige, begav jeg mig derop og overraskedes ved at see maaskee over 150 Mennesker, som toge de udstillede Sager i Øiesyn«.

Efter en præsentation af rådhuset og kunstsamlingen på loftet følger omtalen af den historiske samling:

»I Raadhusets store Sal findes opstillet en Samling af en anden Art, nemlig de mange Ting, som danne »den historisk-antiquariske Samling». Det er unægtelig, at den store Sal, hvori Samlingen er opstillet, og som kun enkelte Gange om Aaret benyttes til større Møder, ved at tjene som Locale for en saadan Samling faaer en ypperlig Anvendelse. Samlingen, der er paabegyndt i dette Foraar, er ingenlunde ubetydelig, og den er forbausende stor, naar man tænker paa, i hvor kort Tid, den er blevet til det, den er«. 
Det fremhæves, at der er udstillet meget fra stenalderen, mindre fra bronzealderen og kun lidt fra middelalderen. Anmelderen har dog hæftet sig ved sværd, røgelseskar og sigiller.

"... Det, som tiltalte mig meget ved denne Samling, var Maaden, hvorpaa den blev foreviist. Flere af Bestyrelsens Medlemmer vare bestandig i Bevægelse med at forevise og forklare Sagerne lige fra »Kjøkkenmøddingen« ved Meilgaard til Resens Prospect af Aarhuus, og de besøgende flokkedes ganske som i gamle Dage i »det oldnordiske Museum«, dengang da dette ikke var for stort til at blive foreviist for de Enkelte og for at see paa Stykkerne.....

Samlingen var åben et par søndage om måneden og om lørdagen for landboerne. Ved Skt. Olufs Marked var den blevet besøgt af 12-1500 landboere, der havde været glade for at nyde gratis markedsglæder. Til sidst kom et hjertesuk: Selskabet havde kun 100 medlemmer. Det var for få til at sikre de mange "stykker«, der kun făr betydning, når de ses i sammenhæng. ${ }^{13}$

I Ârhus var således blevet indrettet en historisk samling i byens mest fornemme og repræsentative verdslige rum, og nogle af byens mest prominente borgere foreviste den. I det små blev i Århus levet op til de europæiske forbilleder, hvor museumsbygninger fremstod som templer og paladser. $^{14}$

\section{Bestyrelsen}

Ledelsen var fra starten den arbejdende bestyrelse, der arbejdede vederlagsfrit for museet og i givet fald kun fik dækket sine udlæg.

Blandt bestyrelsens medlemmer er der grund til at fremhæve nogle enkelte. Frem til sin død var stiftamtmand Thorkild Chr. Dahl (1807-72) bestyrelsens formand ( fig. 1). Han ydede det historisk-antikvariske selskab meget stor velvilje, men valgte i øvrigt at anvende sin enorme arbejdsevne på andre felter. Drivkraften bag det grundlæggende arbejde var bestyrelsens sekretær, Edv. Erslev (1824-92), der da var adjunkt ved Århus Katedralskole (fig. 2). Han havde taget magisterkonferens i naturhistorie. Midt i livet havde han især kastet sig over arkæologien. Han var startet som adjunkt i Roskilde og havde da foretaget undersøgelser af køkkenmøddinger. Ret forståeligt var der da en udbredt tilbøjelighed til at henregne arkæologi til naturvidenskaberne. ${ }^{15}$ Sine sidste mange år koncentrerede han sig udelukkende om geografi.

Sekretæren i udvalget for folkeoplysningens fremme skrev siden om ham : »... med det ... vakte Grundsyn paa Naturen og dens Forhold til Mennesket og dets Kultur følte han snart, i hvilken Grad Geografien var vanrøgtet i Skolen, idet dette Fag da var forsumpet i Navne og Talrækker, uden synderlig Nytte for Livet og i Skolen til Pine og Plage for Ungdommen. 

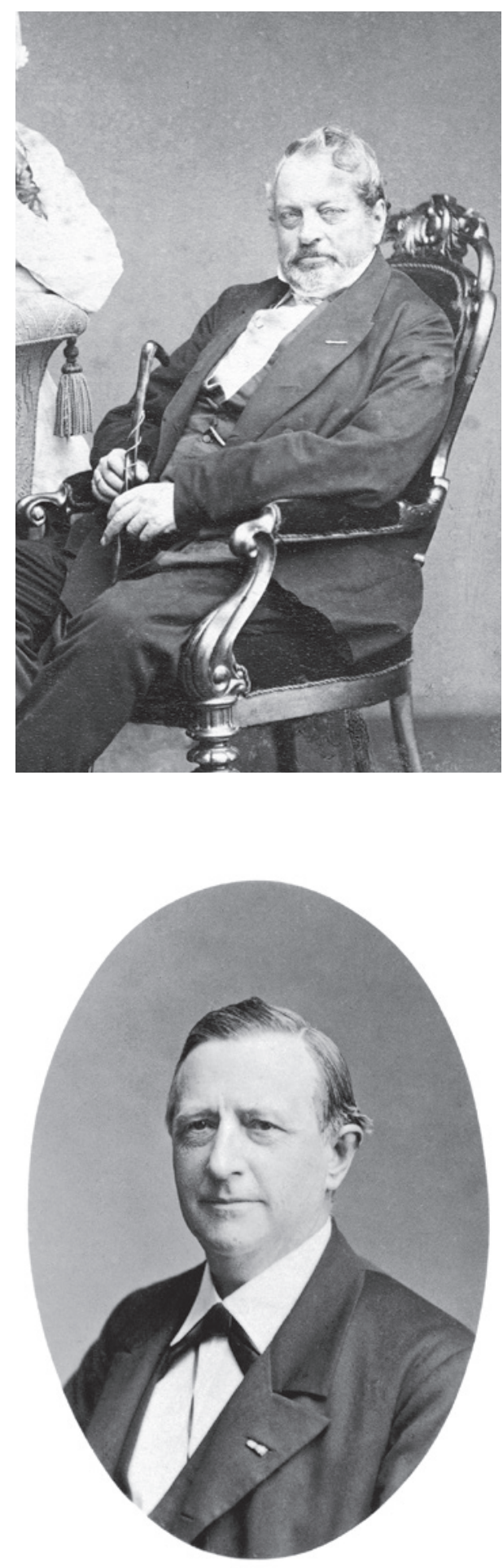

Fig. 1. Thorkild Chr. Dahl, stiftamtmand og ejer af Moesgård, blev museets første formand. Han interesserede sig levende for alt, hvad der havde med historie og oldtid at gøre og lod foretage registreringer og udgravninger af oldtidsfund på Moesgård. Foto o. 1870. - Lokalhistorisk Samling. Århus Kommunes Biblioteker.

Thorkild Christian Dahl, Lord Lieutenant and owner of the manor of Moesgård, was the first chairman of the museum. He was deeply interested in history and prehistory and had prehistoric finds registered and excavated on his estate. Photo from c.1870.

Fig. 2. Edvard Erslev, magister i zoologi, adjunkt i Roskilde og siden i Århus. I Roskilde-tiden kom han med i udforskning af køkkenmøddinger, og interessen for arkæologi blev vakt. Hans hele virke var båret af $\varnothing n s k e t$ om at gøre tingene levende og forståelige for bredere kredse. - Det Kongelige Bibliotek.

Edvard Erslev was a zoologist and lecturer in Roskilde and later Århus. While living in Roskilde he became engaged in the investigation of kitchen middens, which aroused his interest in archaeology. His activities were rooted in a wish to make the public experience and understand the past. 
Erslev vilde have de golde Remser ombyttede med nyttige Oplysninger, der kunde fremme Ungdommens Aandsudvikling, skærpe dens Blik, og styrke dens Fædrelandskærlighed «. ${ }^{16}$

Ejler Haugsted, en af hans arvtagere ved museet i Århus, lærte som barn at læse efter en af hans lærebøger i geografi. ${ }^{17}$ Det har uden tvivl været de samme grundholdninger og det samme menneskesyn, der har ligget bag hans virke som lærer og museumsmand.

Han tog referat fra bestyrelsesmøderne og førte tilvækstprotokollerne, opbyggede udstillingen, ligesom han som oftest stod for forevisningerne af samlingerne.

Konsul J.M. Mørk (1827-89) bør også nævnes. Han var optaget af meget andet; først som folketingsmand for Højre og siden som ansvarshavende redaktør for Århus Stiftstidende, men han var medlem af kunstmuseets bestyrelse frem til sin død og i samme tidsrum med en kort afbrydelse medlem af bestyrelsen for Historisk-Antikvarisk Selskab. Han har stået som bindeled til kunstmuseet og for kontinuitet i arbejdet. ${ }^{18}$

\section{Lokaler på rådhuset}

Allerede før stiftelsen var mulighederne for at få lokaler på rådhuset blevet undersøgt, ${ }^{19}$ og i marts 1861 blev sendt en ansøgning til kunstmuseets bestyrelse, om Historisk-Antikvarisk Selskab måtte bruge et af dettes lokaler på rådhusets loft (fig. 3). Det gav anledning til en følelsesladet diskussion i kunstmuseets bestyrelse, men tilladelsen blev givet,og det nye museum flyttede kort tid efter ind. ${ }^{20}$ I øvrigt var der fra starten og skulle altid forblive vandtæette skodder mellem kunstsamlingen og det historiske museum.

Det var imidlertid lige før, man kunne have sparet sig kævlet i kunstmuseets bestyrelse. I oktober 1861 gav Århus byråd sin tilladelse til, at Historisk-Antikvarisk Selskab kunne fă til huse i rådhusets sal. ${ }^{21}$ Den blev også kaldt »Malerisalen«, fordi der hang en række historiske malerier her.

Det forholdt sig så praktisk, at der i Århus allerede fandtes flere antikvariske samlinger, der kom til at danne grundstammen i den nye offentlige samling. Det drejede sig om en oldsagssamling, som oberst Julius Høegh-Guldberg havde skabt ved udgravninger, og Stiftbibliotekets og Katedralskolens samlinger. Sidstnævnte havde fabrikant E. Mehl (1815-90) yderligere overdraget en oldsagssamling. Han indtrådte i selskabets bestyrelse og solgte i 1862 til selskabet en betydelig møntsamling, som han og hans fader havde skabt. Han modtog en obligation på 100 rigsdaler for sølvværdien. ${ }^{22}$

Samlingerne voksede imidlertid hurtigt. Der blev efterlyst oldsager, og i de første år kom adskillige bidrag. Efter mindre end to måneders virke var samlingen oppe på 500 numre. ${ }^{23}$ Der var endnu ikke et større marked 


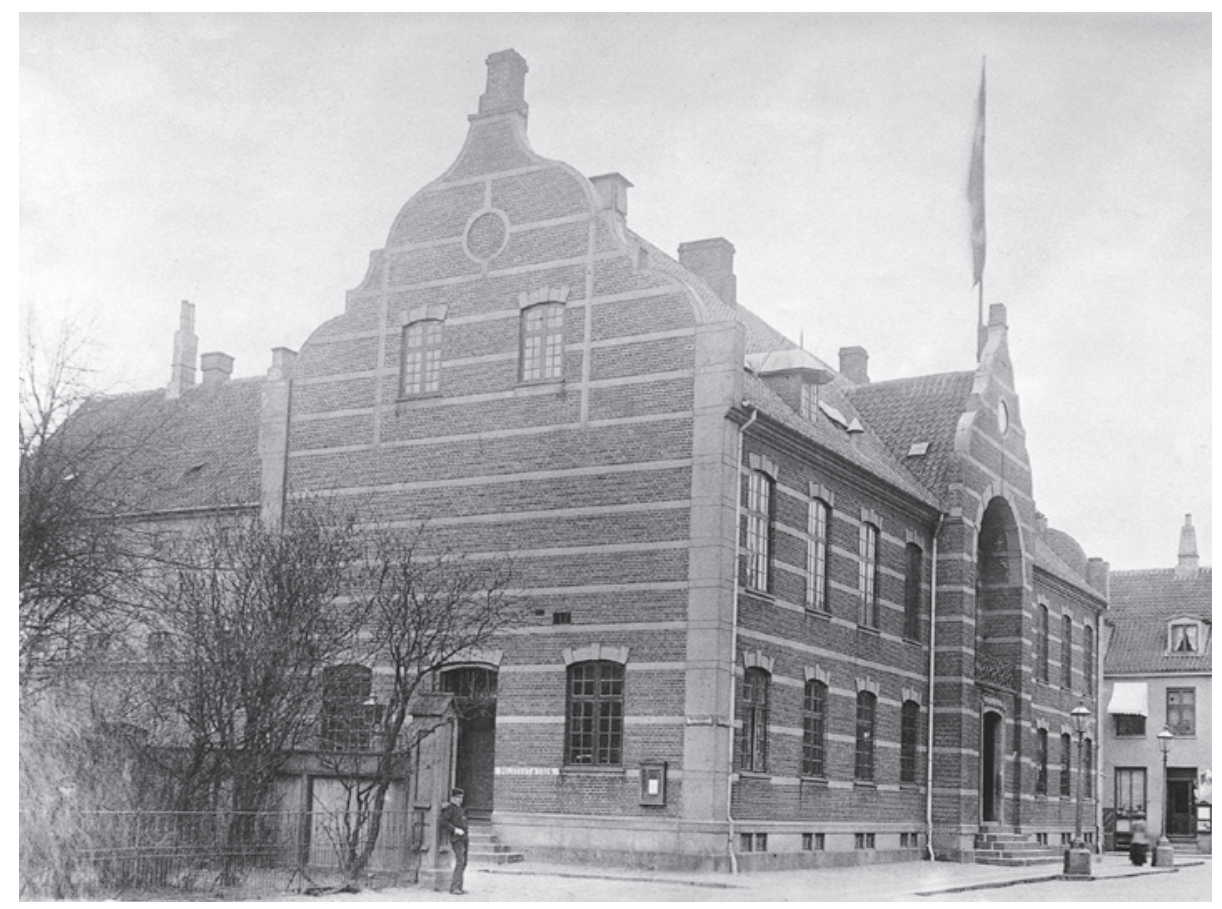

Fig. 3. Rådhuset nord for Domkirken, der blev indviet i 1857. En kort overgang havde den historiske samling til huse hos kunstsamlingen på loftet ved østgavlen. Derefter blev den historiske samling opstillet i rådhusets sal. - Lokalhistorisk Samling. Århus Kommunes Biblioteker.

The Town Hall, from 1857, north of the cathedral. It housed for a short while the historical collection together with the art collection on the top floor to the east. Later, the historical collection was exhibited in the hall.

for almindelige oldsager. Bidragene og bidragyderne blev offentliggjort i Århus Stiftstidende. Derved blev der også skaffet bidragyderne positiv offentlig omtale. ${ }^{24}$ Alligevel understregede museet, at det i modsætning til rygter betalte fuld pris for oldsager og opfordrede publikum til at undgå opkøbere og mellemmænd. I 1863 havde det repræsentanter i Skanderborg, Hobro, Silkeborg, Odder, Randers og Grenå, der tog imod oldsager i deres respektive områder. ${ }^{25}$

Fra starten forsøgte bestyrelsen at skaffe såkaldte korresponderende medlemmer i omegnen. Et af de første var godsinspektør Kruse (1804-81) på Samsø, hvis ideer og virke faldt godt sammen med bestræbelserne bag samlingen i Århus. ${ }^{26}$

Det første par år holdt bestyrelsen også offentlige møder som lovet. Det første allerede 26. april 1861. Her fortalte formanden og sekretæren om 
foreningen, og blandt flere faglige indlæg var et fra konsul Mørk, der fortalte om en runesten, han havde fundet i Århus havn sammen med et andet bestyrelsesmedlem, mens Erslev fortalte om køkkenmøddinger. ${ }^{27}$

\section{Forholdet til København}

Allerede i 1818 var det blevet bestemt ved lov, at samlinger uden for København skulle betragtes som filialer af Oldnordisk Museum, og såfremt de kom i besiddelse af sjældenheder, skulle disse afleveres til museet i København. ${ }^{28}$ Derfor indeholdt selskabets vedtægter bestemmelser om, at såfremt det kom i besiddelse af genstande, som de offentlige samlinger i København måtte mangle og gerne ville i besiddelse af, skulle disse afleveres mod genstande, som kunne have interesse for museet i Århus. Eneste begrænsning var, hvis gaver til museet i Århus var givet med den klausul, at de ikke måtte overdrages til andre.

Samarbejdet med Oldnordisk Museum gik i begyndelsen gnidningsfrit. C.J. Thomsen vidste godt, han havde få reelle magtmidler over for provinsmuseerne, og på den anden side kunne han kun være interesseret $\mathrm{i}$ deres virke. De gjorde deres til, at interessen for fortiden blev øget, og de medvirkede til, at sjældne oldsager ikke blev opkøbt af udenlandske opkøbere. Det springende punkt var, hvad provinsmuseerne skulle have til gengæld for deres pligtige afleveringer. De ville ikke spises af med stereotype stenaldersager. ${ }^{29}$ Over for Thomsen var Erslev en god forhandler, der forlangte gode ting eller ordentlige afstøbninger af bemærkelsesværdige oldsager til gengæld. ${ }^{30}$

Erslev holdt også kontakt med de øvrige provinsmuseer og udvekslede f.eks. i et mindre omfang genstande med samlingen i Flensborg. ${ }^{31}$

\section{Afmatning}

Hurtigt kom en vis afmatning i interessen for arbejdet med samlingen. Ved generalforsamlingen i 1863 mødte kun et medlem udover bestyrelsen op. ${ }^{32}$ Under krigen i 1864 blev samlingen pakket ned og sendt til København. Uden tvivl en klog beslutning i betragtning af den glubende interesse, preusserne og østrigerne viste for danske oldtidsminder. ${ }^{33}$ Det varede en rum tid, inden samlingen blev opstillet igen.

Kort tid herefter besluttede Erslev at flytte til København for at koncentrere sig om sit geografiske forfatterskab. Der kan kun gisnes om årsagerne hertil. Muligvis stod han sig ikke så godt med J.J.A. Worsaae (1821-85), der var blevet direktør for Oldnordisk Museum efter Thomsens død. ${ }^{34}$ Muligvis havde han været for arrogant og havde irriteret de øvrige bestyrelsesmedlemmer. ${ }^{35}$ I 1870 klagede en læserbrevsskribent i Århus Stiftstidende over forsøg på at forbigå hans indsats i tavshed. ${ }^{36}$ 
Naturligt nok opfattede samtiden dette som en stilstandsperiode for museet,${ }^{37}$ men det er i virkeligheden ingen ting mod senere, hvor samlingen skulle opleve langt større nedture.

\section{Nye kræfter}

I forhandlingsprotokollen er der ikke indført nogen mødereferater fra 1863 og indtil august 1869. Katedralskolens rektor, filologen G. Lund (1820-91), optræder da som medlem af bestyrelsen og vælges til sekretær. Det skulle siden vise sig at være et dårligt valg. På sit næste møde optog bestyrelsen stads- og havneingeniør P.B. Obel (1839-1903) og »Hedens opdyrker«, kaptajn Enrico Dalgas (1828-94) som medlemmer. ${ }^{38}$ De bragte nyt initiativ ind i bestyrelsen. Den var da allerede længe blevet tilført stor faglig kunnen af tobaksfabrikant, cand.phil. Andreas Simesen (1816-72). ${ }^{39}$

Bestyrelsen lagde stærkt ud. På forslag af Dalgas besluttedes at skaffe kompetente medlemmer på de vigtigste steder i omegnen, der kunne virke for selskabets interesse ved at opfordre andre til at indtræde og indsende oldsager. En omfattende korrespondance viser, at mange er blevet opfordret til at være såkaldte korresponderende medlemmer, og adskillige gav et positivt svar. ${ }^{40}$ Opfordringen blev gentaget et par år senere i en trykt beretning, som bestyrelsen satte sekretæren og Simesen til at udfærdige. Den blev indrykket $\mathrm{i}$ aviserne $\mathrm{i}$ de omkringliggende byer. ${ }^{41}$

Der viste sig da en fornyet væsentlig interesse for samlingen. Bestyrelsen besluttede så vidt muligt at holde samlingen åben for publikum søndag formiddag fra kl. 11-13. Der blev også afholdt et offentligt møde i juli 1870, hvor sekretær Lund holdt et indlæg især om de organisatoriske forhold, og Simesen holdt ifølge Århus Stiftstidendes referat et klart og anskueligt foredrag om oldgranskningens betydning for at forstå historien og dens udvikling som videnskab. Selskabet havde da 65 medlemmer, hvoraf de otte var udenbys. ${ }^{42}$ Samlingen havde 1274 numre, der hurtigt øgedes til henved 1500, foruden langt over 2000 mønter. Den var udstillet i ni store dobbeltskabe samt et separat skab med skuffer til mønter, så rådhussalen var ved at være overfyldt. ${ }^{43}$ Det var dog ingen ting mod samlingen i Flensborg, der, i den korte tid den eksisterede, nåede op på 10.000 numre. ${ }^{44}$ Bestyrelsen i Århus lod sin samling forsikre for 4.000 rigsdaler. ${ }^{45}$

Ved flere lejligheder slog sekretæren, rektor Lund, til lyd for, at museet foretog nogle udgravninger, og bestyrelsen besluttede allerede i 1869 at sætte sådanne i værk, så snart midlerne tillod det. ${ }^{46}$ Tre år senere fulgte en opfordring til, at der blev foretaget udgravninger, fra Obel, der gjorde bestyrelsen opmærksom på, at det ikke var nok at indsamle oldsager, der dukkede op lejlighedsvis. Der måtte systematiske undersøgelser til. De mindesmærker, der ikke kunne undersøges, burde fredes. ${ }^{47}$ Det var noget 
ret nyt. C. Engelhardt (1825-81), lederen af Flensborgsamlingen, havde gravet meget, men bortset fra Oldnordisk Museum foretog ingen ellers systematiske, videnskabelige udgravninger. ${ }^{48}$

Længe inden havde et medlem af bestyrelsen, Enrico Dalgas, gjort betydelige erfaringer med udgravninger. Vejvæsenet var da underlagt militæret, og som officer i ingeniørkorpsets vejdirektion var han blevet inspektør for det østjyske vejnet og havde i den forbindelse i 1861 stået for udgravningen af flere veludstyrede jordfæstegrave fra yngre romersk jernalder ved Snåstrup Mølle. Dalgas kontaktede Thomsen på Oldnordisk Museum, men det meste af fundet sammen med sagsakter blev afleveret til museet i Århus. ${ }^{49}$ Oldnordisk Museum/Nationalmuseet har betragtet sagen for så vigtig, at det flere gange adskillige år senere henvendte sig for at låne akterne fra Dalgas' tid. ${ }^{50}$

\section{Vilhelm Boye}

Efter stiftamtmand Dahls død i 1872 blev den nye stiftamtmand, T.A.J. Regenburg (1815-95), formand for Historisk-Antikvarisk Selskabs bestyrelse (fig. 4). Han har egentlig en plads i Danmarkshistorien, fordi han som ansvarlig for kirke- og undervisningsvæsenet i Slesvig i begyndelsen af 1850'erne stod for den hårdhændede fordanskningspolitik, der da blev ført. Senere var han som departementschef i ministeriet for Slesvig god til at bakke samlingen i Flensborg op. Samlingen i Århus viste han næppe andet end velvilje.

Obels opfordring til at foretage udgravninger må nok ses i lyset af, at bestyrelsen på dette tidspunkt fik et nyt medlem, som var en af dem herhjemme, der havde størst erfaring med udgravninger. Det var cand.phil. Vilhelm Boye (1837-96), der blev medlem i stedet for Simesen, som var død måneden forinden. Boye havde beskæftiget sig med arkæologi siden sin tidligste ungdom; han havde arbejdet som omviser på Oldnordisk Museum og deltaget i den tids vigtigste udgravninger. Han var meget præget af den nationale bevægelse og arbejdede samtidig med, han opholdt sig i Århus, som journalist for den dansksindede avis »Dannevirke« i Haderslev. Den øvrige bestyrelse var fra starten klar over, at han var en særlig kapacitet på området, og der kom forslag om en række ny tiltag, Boye lovede at påtage sig. Han lovede bl.a. at omordne samlingen og udarbejde en vejledning for besøgende. Worsaae blev også spurgt, om Oldskriftselskabet ville antage en artikel af Boye om samlingens vigtigste indhold, ${ }^{51}$ og der forelå straks et meget imødekommende svar: »... Efter en foreløbig Conference med mine Collegaer i Oldskriftsselskabet tør jeg nok sige, at vi med Fornøielse i Selskabets Aarbøger ville optage en Udsigt af Hr. Cand. Boye om Deres Oldsagssamlings vigtigste Indhold...«. ${ }^{52}$ Dette sidste blev ikke til noget. Derimod realiseredes et forslag fra Dalgas om at kontakte amtsrå- 


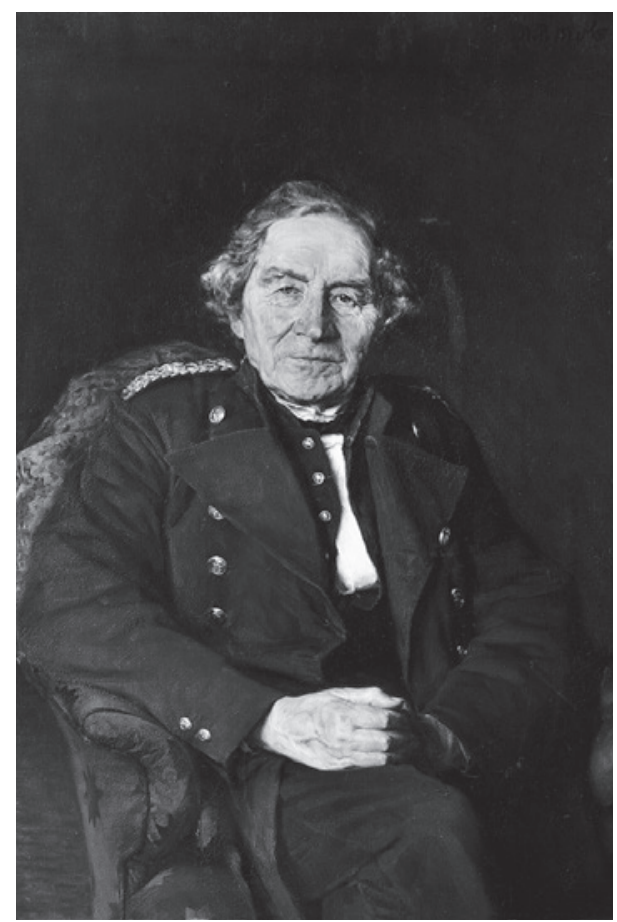

Fig. 4. T.A.J. Regenburg, sønderjyde og efter den første slesvigske krig ansvarlig for kirke- og undervisningsvæsenet i Slesvig. Derefter departementschef i ministeriet for Slesvig, hvor han var en god støtte for samlingen i Flensborg. I sine senere år interesserede han sig mest for sønderjysk folkemindevidenskab og litteratur. Han efterlod en vægtig bogsamling, der indgik i Statsbiblioteket. - Lokalhistorisk Samling. Århus Kommunes Biblioteker.

T.A.J. Regenburg, a southern Jutlander, who was responsible for the church and educational systems in Schleswig after the first Schleswig war. Later he was permanent secretary in the Ministry of Schleswig and a great supporter of the Flensborg collection. During his later years he was mainly interested in Schleswig's folklore and literature. He left a weighty book collection, which went to the State Library.

dene i museets virkekreds med den hensigt, at de gav deres ansatte ved vejvæsenet besked om at være opmærksomme omkring, hvad de måtte støde på af oldsager og bede sognerådene om det samme. I den forbindelse besluttede bestyrelsen at lade udarbejde en kortfattet vejledning i behandling af oldsager, der blev fundet i jorden. Det arbejde blev også overladt til Boye, men skete ikke uden sværdslag, hvilket nogle harmdirrende breve viser. Boye skrev i juni 1874: „Navnlig i den sidste Tid har jeg ... maattet høre Klager over, at vort Selskabs medlemmer vel maa betale det fastsatte aarlige Contingent, men at de aldrig modtage noget Vederlag derfor, ligesom, tilføies der, det tyder paa, at Selskabets Virksomhed overhovedet er standset...«.

Han minder om, at han havde udarbejdet en oversigt over selskabets tilvækst i sidste halvdel af 1873 og vejledningen i udgravning, hvis udgivelser er blevet syltet af bestyrelsen, og slutter: „Men da jeg ikke længere vil være meddelagtig i Bestyrelsens Ansvar ligeoverfor Selskabets Medlemmer, og ligesaalidt vil finde mig i den Haan, der ved disse to Leiligheder er bleven viist mig personlig, erklærer jeg herved, at jeg fremdeles fastholder mit Ønske om at udtræde af Bestyrelsen, saafremt begge Manuscripter ikke blive bragte tilveie inden otte Dage « ${ }^{53}$.

Konsul Mørk påtog sig ansvaret og forlod bestyrelsen med disse ord: 
"...skal jeg lige overfor Hr. Boyes Brev giøre mit til at holde sammen paa Bestyrelsen ved herved at udtræede af den «. ${ }^{54}$

Kort tid efter blev oversigten over tilvæksten offentliggjort. ${ }^{55} \mathrm{Og}$ Boyes „Vejledning til Udgravning af Oldsager og deres foreløbige Behandling» forelå senere på året, trykt i 2.000 eksemplarer, et efter den tids forhold meget stort oplag. Hæfterne blev solgt for 16 skilling pr. stk. De andre jyske provinsmuseer fik det tilbudt til særpris. De almindelige medlemmer og de korresponderende fik et gratis eksemplar hver ligesom de personer, der havde vist selskabet særlig interesse. Aviserne i stiftet blev overdraget anmeldelseseksemplarer, og endelig fik en række højskoler. ${ }^{56}$

Boye fungerede på mange måder som en form for uformel inspektør ved museet. Han overtog snart sekretærens hverv med at føre tilvækstprotokollen, og i den udstrækning, det var ham muligt, stod han for forevisning af samlingen. De øvrige bestyrelsesmedlemmer havde heller ikke altid tid til at forevise. I så fald skulle arrestforvareren være til stede. ${ }^{57}$

Kort efter nytår 1876 udtræeder Boye af bestyrelsen som følge af bortrejse fra byen, og Mørk genindtræder.

\section{Nye lokaler}

Det havde længe stået klart, at samlingernes lokaler på rådhuset slet ikke var tilstrækkelige, og kredsen bag kunstsamlingen begyndte at indsamle midler, så der kunne blive bygget en ny museumsbygning. I vinteren 1872 blev fremlagt planer for en ny, selvstændig museumsbygning i bispegårdens have ud til Kannikegade. Den skulle indeholde malerisamlingen, oldsagssamlingen og Stiftsbiblioteket, og så skulle der også være et læseværelse m.v. ${ }^{58}$ Det blev imidlertid ikke til noget, og mølleejer A.S. Weis forærede den grund, der var fremkommet, efter at mølledammen var blevet kastet til, fordi møllen var gået over til dampdrift. Her opførtes museumsbygningen, der var klar til indvielse i 1877 (fig. 5). ${ }^{59}$ Der var bare det problem, at Weis ikke ville have den historiske samling i en museumsbygning for kunst. ${ }^{60} \mathrm{I}$ første omgang undersøgte han mulighederne for den salomoniske løsning, at der blev opført en særskilt bygning til den historiske samling. ${ }^{61}$ Dernæst bestræbte han sig for, at Kunstmuseet anskaffede så mange gipsafstøbninger, både af antik og dansk kunst, som muligt, så der kun blev lidt plads til overs. I første omgang var der derfor kun afsat plads til Stiftsbiblioteket i den nye museumsbygning. ${ }^{62}$

I de svære forhandlinger, der foregik, trak bestyrelsen for det HistoriskAntikvariske Selskab forståeligt nok meget på Mørk, der også var medlem af bestyrelsen for Kunstmuseet. ${ }^{63}$ Selskabet nød stor forstålse i Århus kommune og amt, der administrerede rådhusbygningen. I første omgang blev Selskabet tilbudt at måtte overtage kunstsamlingens lokaler. I anden omgang, at det måtte blive i rådhussalen indtil videre, da bestyrelsen ikke 


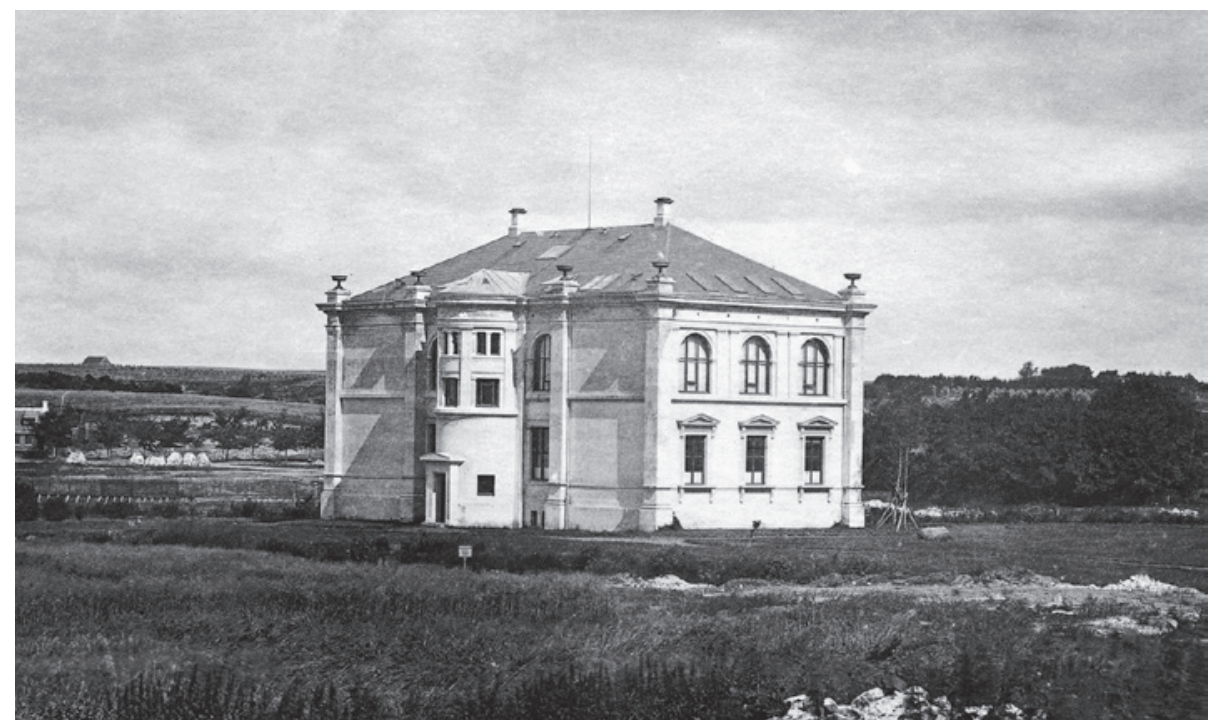

Fig. 5. Den nyopførte museumsbygning som den lå så godt som på åben mark i 1877. Den virker som et palads, der hviler i sig selv. - Lokalhistorisk Samling. Århus Kommunes Biblioteker.

The new museum building in 1877 in what was then still an open area. It almost resembles a palace.

ønskede en midlertidig løsning, men håbede på et lokale, der helt kunne leve op til samlingens behov. ${ }^{64}$ Stiftsbiblioteket, hvis øverste ansvarlige var rektor Lund, blev imidlertid slået sammen med Katedralskolens bibliotek, og i 1881 kunne den historiske samling flytte ind i den nye museumsbygning, men vel at mærke kun i to pulterkammeragtige værelser på loftet. Resten af loftet var blevet indrettet til bolig for kustoden.

Det nye museum lå så godt som ude på åben mark. Det virkede sluttet og udstrålede selvfølelse som et renæssancepalads.

Mens alt dette stod på, lå den historiske samling nærmest i dvale.

\section{Stilstand og ny opblomstring}

I tilvækstprotokollen er nogle blanke sider. Her har en senere formand, Ollendorff, føjet ind: „Fra 1875 til 1884 stod hele Sagen i Stampe og saa godt som intet erhvervedes ${ }^{65}{ }^{65}$

Lund behandlede enkelte sager og var især påpasselig med at få dækket sine egne udlæg. ${ }^{66}$ I 1878 sendte han en forespørgsel til Worsaae på Oldnordisk Museum om museumssager. Desuden havde han lovet russiske 
filologkollegaer at skaffe oldsager og bad Worsaae syne et par hundrede stenaldersager, han havde skaffet i den anledning. ${ }^{67}$

Noget skete der dog på museet. Det annonceredes i 1879, at museet havde åbent uden betaling hver lørdag fra kl. 11-13 og hver søndag kl. 12-14 og 16-18. Skoleklasser kunne komme gratis ind uden for normal åbningstid. ${ }^{68}$ En af dem, der besøgte museet, var overretssagfører Chr. Kjer (18391934) (fig. 6). Han besluttede da at forære museet sin samling af 600 til 700 meget sjældne danske mønter og medaljer, da han kunne se, den ville kunne supplere museets samling meget godt. ${ }^{69} \mathrm{Og}$ det var også fra ham, museets redning skulle komme.

\section{Chr. Kjer}

Det må være gået op for Kjer, at museet ikke kun havde brug for hans møntsamling, men også hans arbejdskraft. I marts 1883 holdt bestyrelsen møde for første gang i syv år. Anledning var, at fabrikant Mehl, der havde været med fra starten, ønskede at fratræde som kasserer og udtræde af bestyrelsen, da han flyttede fra byen. Bestyrelsen udbetalte ham ved samme lejlighed det mere end 20-årige tilgodehavende for møntsamlingen. Kjer afløste ham som bestyrelsesmedlem og kasserer. ${ }^{70}$ To år senere meddelte også Lund, at han flyttede fra byen, udtrådte af bestyrelsen, ud-

Fig. 6. Chr. Kjer, overretssagfører. Han var engageret i meget andet end museet. Bl.a. i to lange perioder medlem af Århus byråd, valgt af Højre og en af drivkræfterne bag Århus kommunes køb af Marselisborg. Skrev desuden vægtige retshistoriske artikler. Usædvanlig velmenende over for de mange opgaver, han påtog sig, men bredte sig måske over lidt for meget. - Det Kongelige Bibliotek.

The lawyer, Christian Kjær, was engaged in numerous other types of work besides the museum. He served for two long terms as a Conservative member of Àrhus Town Council. He was one of the promoters behind the town council's purchase of Marselisborg Castle. Christian Kjær wrote weighty articles on legal history. He was very well-meaning when it came to all the tasks he took on - but perhaps he undertook more than he could realistically carry through.

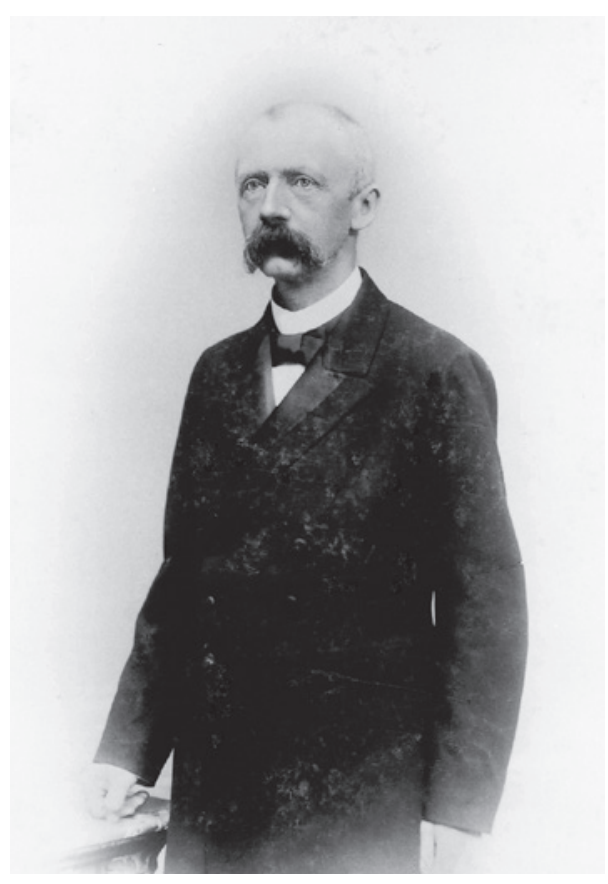


meldte sig af selskabet, og han bad om, at de oldsager, protokoller, bøger og papirer af museets, som han lå inde med, blev afhentede. Kjer blev derefter også sekretær. ${ }^{71}$ I praksis fungerede han også som formand. Han indkaldte til møderne og skrev til stiftamtmand Regenburg, der residerede i Skanderborg, at det ikke var nødvendigt, han mødte. Ofte blev der udsendt skrivelser til cirkulation blandt bestyrelsens medlemmer, hvor de blev bedt om at skrive på, om de var for eller mod beslutninger.

Selvom museet i Århus kan takke Kjer for sin fortsatte eksistens, var han engageret i så meget, at arbejdet for museet kun kunne blive venstrehåndsarbejde. Ved siden af sagførerforretningen havde han været bankdirektør. Han var i to lange perioder medlem af byrådet for Højre. På samme tid, som han passede museets sager fra sit sagførerkontor, vikarierede han for den kongeligt udnævnte borgmester. Dertil kom, at to af hans sønner døde, mens han var hængt op med museumssager. Og så havde han også et retshistorisk forfatterskab. ${ }^{72}$ Udover Oldnordisk Museum korresponderede Kjer med tidens førende fagfolk som zoologen Japetus Steenstrup og dennes søn historieprofessoren Johannes Steenstrup, ${ }^{73}$ og han var med til at stifte en foredragsforening i Århus, der lagde ud med et foredrag af historieprofessoren $\mathrm{Kr}$. Erslev, nevø af museets primus motor i de første år. ${ }^{74}$ Det er derfor forståeligt, når Kjer skriver til Sophus Müller på Oldnordisk Museum, at han prioriterede, hvad han anvendte sin fritid til. ${ }^{75}$

Den første store faglige opgave, Kjer tog fat på, var en nyopstilling af samlingen på museumsbygningens loft, hvis den i det hele taget havde været opstillet forinden. Bestyrelsen søgte om at få tildelt yderligere to værelser på loftet og fik et. Kjer valgte da at dele det største værelse ved hjælp af en såkaldt spansk væg. Der var således en sektion til stenalderen og en til jernalderen og bronzealderen. De to små værelser blev indrettet til henholdsvis middelalder og nyere tid. Han var ked af, han kun havde mulighed for at anbringe montren med romerske mønter i stenalderlokalet. ${ }^{76}$

Kjer fik mulighed for ret hurtigt at nedprioritere sin faglige indsats, da bestyrelsen fik nye, endda særdeles fagligt kompetente medlemmer. I 1886 optog bestyrelsen kaptajn G.V. Smith (1848-1917) og læge J.M. Frisch (1850-1931) som medlemmer. Sidstnævnte udtrådte dog året efter, da han ikke fandt medlemskab af bestyrelsen foreneligt med at være privatsamler. ${ }^{77}$ Smith var kaptajn ved fodfolket og kom samtidig til at betyde særdeles meget for museets faglige arbejde. Det samme gælder i højeste grad overretssagfører W.O.A. Reeh (1850-1900) og korpslæge M.C.C. Iuul (184798), der kom med i bestyrelsen i 1888.

Museets økonomiske grundlag var medlemsbidragene og gaver. Uden foræringer af genstandene og bestyrelsens frivillige arbejde, havde driften været helt umulig. Netop i 1880'erne stod mange provinsmuseer ved en korsvej: Hvordan skulle driften sikres på længere sigt? Det hele stod og 
faldt med, hvilken indflydelse og økonomisk formåen, mændene bag museerne havde. Odense er et meget tydeligt eksempel. Det hele afhang af en lokal matador, apoteker Lotze (1825-93). Han var velhavende, selv samler og et meget indflydelsesrigt medlem af byrådet. Museet i Odense blev derfor på et tidligt tidspunkt overtaget af kommunen, og i de sjældne tilfælde, hvor Lotze ikke kunne skaffe midler fra private eller offentlige, skød han selv penge i driften. ${ }^{78}$

Kjer havde stor indflydelse og gode forbindelser, mens hans interesser og engagement var mere spredte, så han var ikke i stand til at konsolidere museet i Århus på samme måde, som det skete i Odense.

På denne tid blev provinsmuseernes forhold til Oldnordisk Museum meget vigtig. Her spillede deres forskellige forudsætninger afgørende ind.

\section{Forholdet til sagkundskaben}

J.J.A. Worsaae, der var direktør for Oldnordisk Museum, var først og fremmest ude på at få tingene til at glide: »I det hele taget synes Worsaae at have været en Mand, der forstod Samarbejdets Betydning «. ${ }^{79}$

Den sparsomme korrespondance med museet i Århus efterlader ikke spor af gnidninger. Museet i Århus viste i øvrigt sin imødekommenhed ved bl.a. at udlevere en kronehalsring fra førromersk jernalder, som Thomsen forgæves havde forsøgt at få fat i. Til gengæld gav Worsaae ikke alene en afstøbning af kronen, men bl.a. også nogle ravperler samt nogle stykker fra det berømte Viemosefund. ${ }^{80}$

Efter Worsaaes død i 1885 blev den aldersstegne C.F. Herbst (1818-1911) direktør af navn og den dynamiske og systematiske, men meget kontroversielle, dr.phil. Sophus Müller (1846-1934), af gavn. ${ }^{81}$ Sophus Müller var beundret for sin vid og berygtet for sin arrogance.

Historierne om det sidste bliver ikke dårligere af at blive fortalt. For blot at gengive en enkelt: Grundlæggeren af Den Gamle By, P. Holm, kunne berette, at en ulønnet bestyrelsesformand havde indbudt Sophus Müller til middag og fået det svar: »Mener De, jeg spiser hos en af mine Underordnede«? ${ }^{82}$

Det korte af det lange er, at Müller ønskede museumsvirksomheden samlet under Oldnordisk Museum i København. Bag denne grundholdning lå væsentlige faglige hensyn. Genstandene i sig selv var de vigtigste forskningsobjekter. Derfor var det vigtigt at have de betydeligste genstande samlet på et sted. ${ }^{83}$ Dernæst var det hans vision, at forhistorisk arkæologi fik sin endelige anerkendelse som universitetsfag. ${ }^{84}$ For ham var det derfor vigtigt, at faget holdt sin sti ren og ikke gav plads for fuskere.

Eftertiden har især hæftet sig ved de gnidninger, der var mellem Sophus Müller og provinsmuseerne i 1880'erne, men det største opgør skulle 
komme efter århundredskiftet, da de såkaldte kulturhistoriske museer blev oprettet..$^{85}$ Det var så sandelig ikke mindst tilfældet for Århus' vedkommende.

De fleste gik ud fra, at Sophus Müller skulle mødes med krybende underdanighed. Ville man på talefod med ham, skulle man imidlertid kunne give ham svar på tiltale og i givet fald også kunne sætte ham stolen for døren. ${ }^{86}$

Til at begynde med forespurgte Kjer i underdanige vendinger Müller om elementære museumsspørgsmål. Han beder om megen hjælp til opstillingen og Smith og Frisch om at holde igen med arbejdet, indtil Müller har set det. Han spørger også, om opstillingen skulle følge rækken efter Worsaaes »Nordiske Oldsager" eller Madsens »Afbildninger", og om førstnævnte værk fandtes i en nyere udgave end den fra 1859. Müller svarer, at førstnævnte giver mest mening, men ingen af dem er fuldkomne. ${ }^{87}$

Hurtigt lærte Kjer dog at give igen over for Müller og sætte ham stolen for døren, og Kjer bevarede et godt forhold til Müller, der bl.a. overnattede hos ham, når han var i Århus.

"Bedste tak fremdeles for de meget behagelige Dage, jeg tilbragte hos Dem, og min ærbødigste Compliment til Deres Frue«, kunne Müller kvittere med at skrive. ${ }^{88}$

Da det drejede sig om modydelser for de stykker, der måtte afleveres til Oldnordisk Museum, talte Kjer med store bogstaver og henviste til Worsaaes tid, hvilket blev taget ad notam. ${ }^{89}$

Sådan var forholdene i Århus, da en protestbølge mod Oldnordisk Museums dominans bredte sig blandt provinsmuseerne.

\section{Provinsmuseernes oprør}

Det hele startede med, at Aalborg Historiske Museum i 1885 ansøgte Kirke- og Undervisningsministeriet om et årligt tilskud på $2.000 \mathrm{kr}$. Oldnordisk Museum indstillede for det første, at tilskuddet blev sat ned til $1.000 \mathrm{kr}$. årligt, da det burde ydes til alle de syv provinsmuseer, der var på det tidspunkt. Dernæst burde der opstilles en række stramme betingelser:

Oldnordisk Museum skulle føre tilsyn med provinsmuseerne og ved tilsynet skulle afgøres hvilke genstande, der skulle afleveres til Oldnordisk Museum. I sidste ende bestemte Oldnordisk Museum. Den sidste ordning eksisterede som bekendt allerede for bl.a. museet i Århus. Endvidere skulle den tilsynsførende vejlede ved indkøb, opstilling, nummerering, protokolføring m.v. Tilskuddet måtte ikke anvendes til inventar, opsyn, rengøring m.v. Hertil kom, at udgravninger måtte foretages under tilsyn af Oldnordisk Museum. Det skulle til gengæeld yde videnskabelig støtte til provinsmuseerne. ${ }^{90}$ 
På initiativ af Aalborg-museets formand afholdt museerne et fællesmøde om sagen i maj 1887. Modstanden mod Oldnordisk Museum blev ført af apoteker Lotze fra Odense, der både havde sin egen formue og Odense kommune i ryggen. Indledningsvis holdt provinsmuseerne møde uden Müllers tilstedeværelse. Det var Kjer imod. Han ønskede så tæt samarbejde med København som muligt og var fra starten ikke på linie med de andre provinsmuseer. ${ }^{91}$ På formødet sagde Kjer, at pligten til aflevering ikke var noget problem, sådan som den havde fungeret for museet i Århus. På det egentlige møde udtalte Lotze sig med forsigtighed, mens Kjer i et skarpt indlæg mindede om, at afbrydelse af samarbejdet kunne skade Oldnordisk Museum.

Tilskuddet blev herefter bevilget af ministeriet på Oldnordisk Museums betingelser med en yderligere tilføjelse, at provinsmuseerne skulle indsende regnskab til Oldnordisk Museum. ${ }^{92}$

Hermed var lagt den linie i forholdet til Oldnordisk Museum, som museet i Århus skulle følge de næste mange år. Den havde rod i den strategi, Kjer og bestyrelsen havde lagt for museets fremtid.

\section{Nybyggeri}

Det turde være indlysende, at det historisk-antikvariske selskabs lokaler var helt utilfredsstillende. Det havde som bekendt kun tre pulterkammeragtige værelser på museets loft. Kunstmuseet ville også gerne have mere plads. Derfor blev der projekteret opførelse af to sidepavilloner til museumsbygningen, hvoraf den historiske samling skulle kunne disponere over den ene. ${ }^{93}$ Det blev anslået at ville koste $50.000 \mathrm{kr}$. Chr. Kjer og den øvrige bestyrelse mente at kunne skaffe pengene i form af et statstilskud, men de vurderede, at det kun kunne lade sig gøre, hvis de fik opbakning fra Oldnordisk Museum og Sophus Müller. Kjer mødte selv op hos ministeren, men i første omgang satte Kirke- og Undervisningsministeriet det ikke på finansloven.${ }^{94}$ Underhånden antydede ministeren, at $15.000 \mathrm{kr}$. eller måske det halve beløb af den samlede sum kunne bevilges, hvis der skaffedes kommunalt tilskud, og de resterende midler på anden måde skaffedes. I anden omgang mødte kaptajn Smith op hos ministeren, og da det ved en ihærdig hvervekampagne lykkedes at skaffe $25.000 \mathrm{kr}$., bevilgedes et tilsvarende statstilskud..$^{95}$

De nye bygninger kunne indvies 11. juni 1891 (fig. 7). Bl.a. kultusministeren og Sophus Müller var til stede, men formanden for kunstmuseet holdt festtalen, og han talte næsten udelukkende om kunst. ${ }^{96}$

En betingelse for statstilskuddet var, at museerne blev omdannet til selvejende institutioner. Museet bestod herefter af tre uafhængige selvejende institutioner: Kunstafdelingen, Den historiske Afdeling og museumsbygningen, der var en selvejende institution for sig selv under stiftets 


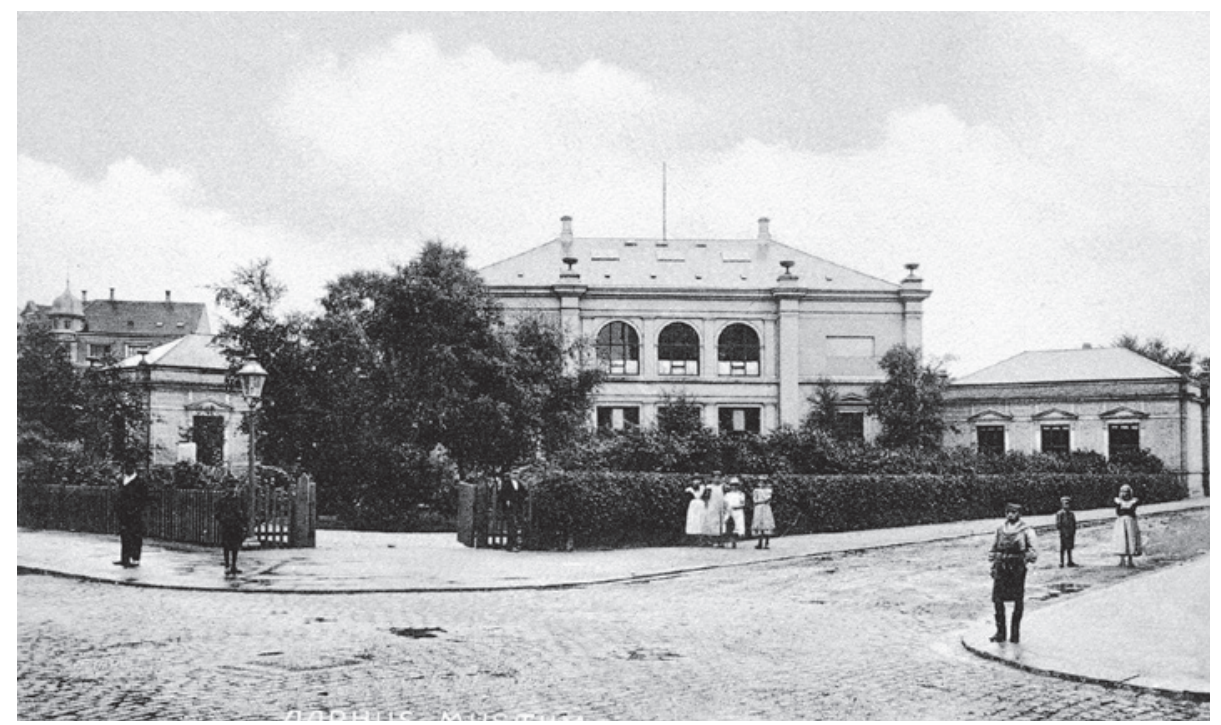

Fig. 7. Museumsbygningerne o. 1905. Pavillonen til højre i billedet rummede bl.a. oldsagssamlingen. - Lokalhistorisk Samling. Århus Kommunes Biblioteker.

The museum buildings around 1905. The pavilion to the right contained the collection of prehistoric artefacts.

tilsyn. Den historiske afdeling blev stillet under Oldnordisk Museums tilsyn, og dens ejendele måtte kun undtagelsesvis afhændes uden Oldnordisk Museums tilladelse.

Oldnordisk Museum var dermed både tilsynsførende som følge af det årlige statstilskud, og i kraft af at det drejede sig om en selvejende institution. Herved var der indgået en håndfæestning for de fremtidige bestyrelser, og deltagelse i det fortsatte oprør mod Nationalmuseet var næsten utænkeligt.

Historisk-Antikvarisk Selskab blev opløst på en ordinær generalforsamling 26. september 1890, men der blev gennem flere år opretholdt en museumsforening uden vedtægter, der altså har fungeret som en uformel støtteforening.

Aarhus Museums historiske Afdeling, som var det officielle navn, skulle ledes af en bestyrelse på seks personer, hvoraf de fire skulle vælges ved selvsupplering, en skulle udpeges af Århus byråd og en af Århus amtsråd. Amtsrådet gav dog fra starten afkald på sin ret til at udpege et medlem. ${ }^{97}$ Bestyrelsen bestod da af fem: Regenburg, Kjer, Smith, Reeh og Iuul. Da den kun kunne vælge de fire medlemmer, bad Kjer stiftamtmand Regenburg om at udtræde, og han overtog selv formandsposten..$^{98}$ Bestyrelsen for bygningen bestod af to medlemmer: En repræsentant for hver afdeling. ${ }^{99}$ 


\section{Museets arbejdsmark}

Der blev udfoldet en livlig aktivitet for at skaffe oldsager til huse. Private opkøbere var blevet et alvorligt problem, og museet appellerede til, at oldsager blev afleveret som foræring og erklærede sig i modsat fald villig til at betale gangbar pris. Det understregedes, at oldsager først og fremmest havde betydning, når de kunne vurderes i sammenhæng og sammenligning med andre. Talrige breve vidner om erhvervelser af oldsager.

Museets virkefelt var bredt. Bortset fra Vendsyssel og Himmerland interesserede det sig for hele Jylland indbefattet Slesvig. Kjer forsøgte at få fat $i$ et egekistefund fra bronzealderen fra Nybøl ved Aabenraa, som museet i Kiel også var ude efter. Ejeren svarede, at han havde afleveret fundet til museet i Aabenraa, selv om han ikke var glad for risikoen for, at det endte syd på, hvor det slet ikke hørte hjemme. ${ }^{100}$

Der kom for alvor gang i museets udgravninger, ved at Oldnordisk Museum tog Kjer med på oplæring. ${ }^{101}$ Snart kunne han overlade dette arbejde til Smith, Reeh og Iuul, og der blev foretaget mange udgravninger. ${ }^{102}$ Det forekom, at Oldnordisk Museum gravede for museet i Århus ved at lade nogle af sine folk foretage udgravninger, som det var interesseret $i,{ }^{103}$ men i hovedsagen klarede Århus-museet det selv og havde ikke betydelige udgifter med at få Oldnordisk Museum til at grave for sig som andre provinsmuseer. ${ }^{104}$

Århus-museets udgravninger foregik som regel på den måde, at ejeren af stedet, som skulle udgraves, blev bedt om at leje arbejdere til at gøre det grove arbejde på museets regning, mens bestyrelsesmedlemmer foretog det sagkyndige arbejde uden andet vederlag end dækning af udgifter. ${ }^{105}$

Det højtliggende Borum sogn med mange bronzealderhøje var et af de steder, hvor Arhus-museet gravede meget. Mest kendt er Borum Eshøj. Højen, der blev fredet i 1854, var ejet af Højballegård. Ved en fejl blev tinglysningen af fredningen ikke indført i skødet, da gården fik ny ejer, så denne begyndte i god tro at fjerne jord fra højen. I 1871 var det kommet så vidt, at både en egekiste og dens indhold kom frem og fik en meget hårdhændet behandling. Nogle bronzesager falbød ejeren til en guldsmed i Århus i den tro, det var guld. Guldsmeden henviste i stedet for til bestyrelsen for Historisk-Antikvarisk Selskab. Simesen og to andre medlemmer af bestyrelsen tog ud og besigtigede stedet, samlede så meget af kistens indhold, som de kunne, og tog det med til Århus samt indhentede så udtømmende beretning om stedet, som det var muligt. Simesen udarbejdede en tyve siders beretning med tre plancher: "Borum-Fundet i April 1871 meddelt ved cand. phil. A. Simesen", der blev indsendt til Oldnordisk Museum. Takket være museet i Århus var en egekiste med indhold blevet reddet. ${ }^{106}$ Worsaae gjorde venligt, men bestemt opmærksom på, at fundet var fremkommet ved en ulovlig udgravning i en fredet høj og derfor burde 
udleveres til Oldnordisk Museum, så det kunne komme under behandling af dettes øvede konservatorer. Museet i Århus svarede, at der var handlet i god tro og bad om lov til at beholde fundet. ${ }^{107}$

Det fik det ikke lov til. Vilhelm Boye ville gerne have foretaget en udgravning, men det blev Conrad Engelhardt, der i 1875 kom til at stå for en stor udgravning af stedet for Oldnordisk Museum, hvorved fremkom yderligere to egekister. ${ }^{108}$

Den næste udgravning i $1891 \mathrm{blev}$ derimod foretaget af museet $\mathrm{i}$ Århus. Ejeren af stedet havde solgt stenkredsen i højen til den lokale møller, men de ville gerne bidrage til, at der blev foretaget en arkæologisk undersøgelse. Den stod Smith og Reeh for. ${ }^{109}$

Det var ikke kun Borum Eshøj, der blev udgravet i Borum. Der blev fundet pælerester i Borum Sø, som Sophus Müller skønnede var fra middelalderen, og knoglerester herfra blev sendt til bedømmelse hos Japetus Steenstrup. I sognet blev ligeledes udgravet adskillige bronzealderhøje, der skulle sløjfes. ${ }^{110}$

Århus-museet gravede også meget i Yding, og Oldnordisk Museum engagerede det til at foretage fredninger. ${ }^{111}$ Mens Smith og Reeh gravede bronzealderhøje ud i Yding og Underup, kom det til en alvorlig kontrovers med Oldnordisk Museum. Kjer skrev til Sophus Müller, at Henry Petersen fra Oldnordisk Museum havde bagtalt dem over for de lokale bønder. Derfor truede Smith og Reeh med at strejke og forlade arbejdet. Kjer fortalte Müller, at disse højt kvalificerede mænd ikke kunne behandles som lønnede hustjenere, og hvis Smith og Reeh gik deres vej, ville han overveje det samme. Der fulgte forklarende og udglattende breve fra Herbst og Müller, der dog tilsyneladende både havde juraen og de saglige hensyn på deres side. Smith og Reeh var uden tilladelse fra Oldnordisk Museum begyndt at grave i høje, der var intakte, og derfor ikke skulle udgraves, men fredes. Pointen var imidlertid, at en opkøber ville være begyndt på at grave $\mathrm{i}$ højene. Til trods for den hårde meningsudveksling dalede de tre herrer næppe i Müllers agtelse. ${ }^{112}$

\section{Glansperiode}

Chr. Kjer trådte ud af museets bestyrelse og kunne overlade dets drift til Smith og Reeh, der efterhånden havde oparbejdet stor faglig kunnen. Sammenlignet med forholdene før og siden havde museet en egentlig glansperiode i 1890'erne.

Kaptajn Smith var formand indtil 1895, hvor han blev forflyttet til København og for øvrigt avancerede til oberstløjtnant (fig. 8). Derefter overtog Reeh formandsposten. Forinden var Reeh blevet udpeget til både bibliotekar og arkivar. 
Fig. 8. G.V. Smith, kaptajn ved fodfolket. Måtte en enkelt gang sige fra over for museumsarbejde, fordi han havde travlt med sine rekrutter, men ydede en så godt som professionel faglig og administrativ indsats for museet og opnåede stor anerkendelse som arkæolog. Foto o. 1900. - Det Kongelige Bibliotek.

G.V. Smith, an infantry captain, at one point had to decline to carry out museum work as he was busy with his recruits, but normally he worked almost professionally in the museum and achieved wide recognition as an archaeologist.

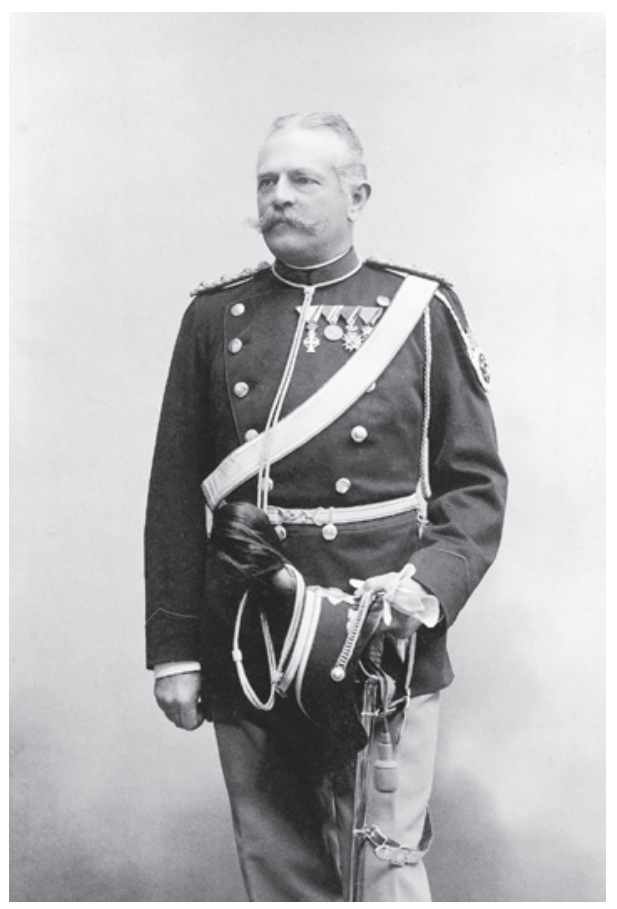

Økonomien bedredes, da Århus Kommune gav et årligt tilskud på efterhånden 400 kr. Hertil kom mindre tilskud fra Århus og Skanderborg amter. Men bestyrelsen måtte gøre, hvad den kunne for at skaffe yderligere tilskud og var også nødsaget til at optage lån. I 1891 blev Sophus Müller bedt om hjælp til et ekstra statstilskud på 3.000 kr. ${ }^{113}$ Århus Museums historiske Afdeling havde på dette tidspunkt et par hundrede medlemmer, der hver betalte det årlige kontingent på 4 kr. ${ }^{114}$

\section{Museumsarbejdet}

Indretningen af den nye museumsbygning krævede sit. Den historiske afdeling havde fået tildelt den vestre pavillon og kunne desuden fortsat disponere over de værelser, den hidtil havde haft på loftet foruden endnu et loftsværelse, som Kunstmuseet afstod. I pavillonen blev der bl.a. runehal og værelser til stenalder, bronzealder og jernalder. Byens historie blev samlet i det største værelse i hovedbygningen. Der blev indrettet et arbejdsværelse med håndbibliotek og rum til arkivsager. Museets bogsamling har været rimelig fyldestgørende. ${ }^{115}$ Flytningen forudsatte, at skabe og montre blev lavet om, og der blev indkøbt nye. Oldnordisk Museum krævede, der blev indkøbt etiketter til genstandene. Samlingen var nu kommet op på ca. 9.000 udstillingsgenstande (fig. 9-10). 

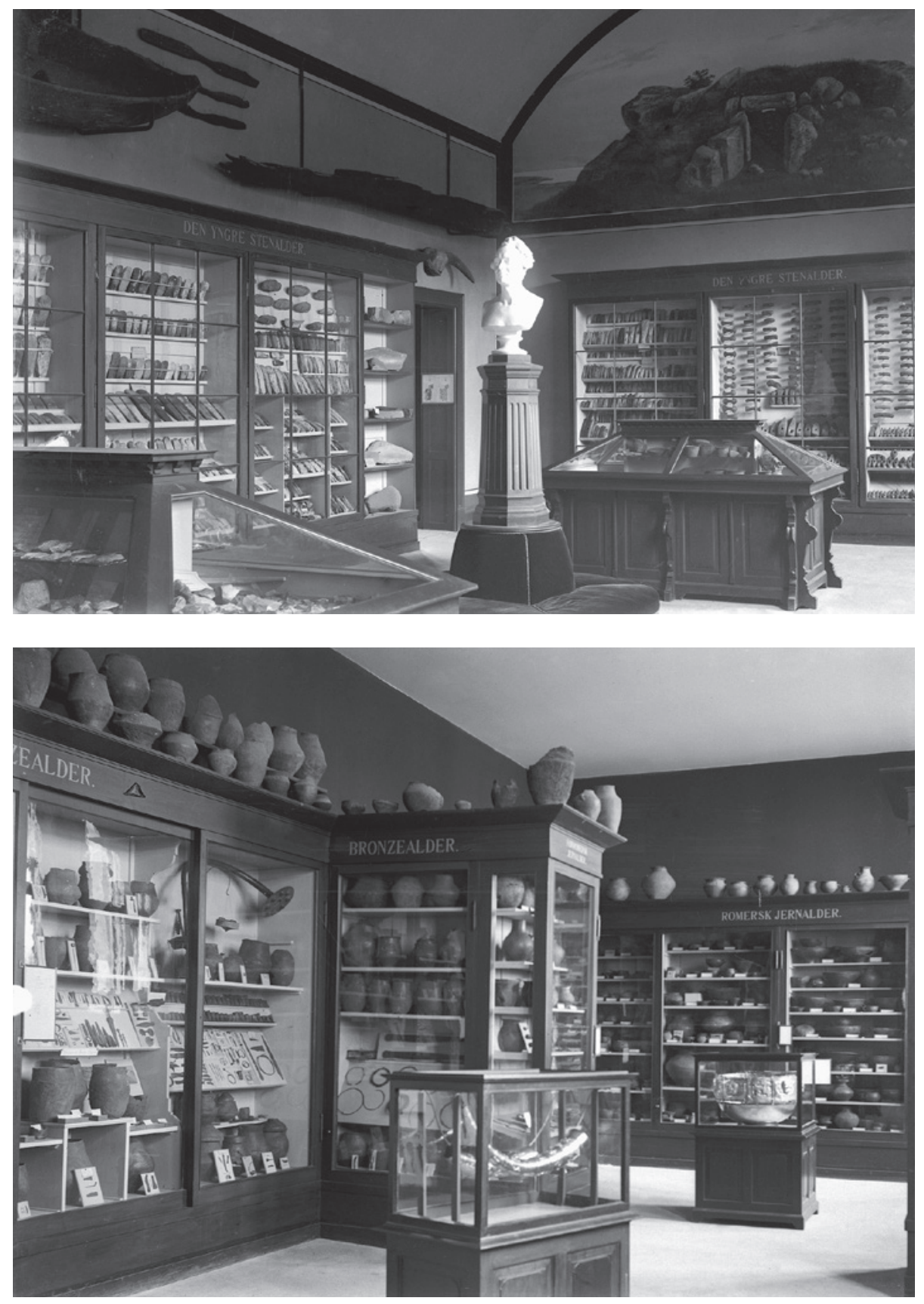

Fig. 9. Oldsagssamlingen o. 1900. Worsaaes buste ses øverst midt i billedet. - Lokalhistorisk Samling. Århus Kommunes Biblioteker.

The collection of prehistoric artefacts around 1900. In the centre of the photo is a bust of J.J.A. Worsaae. 


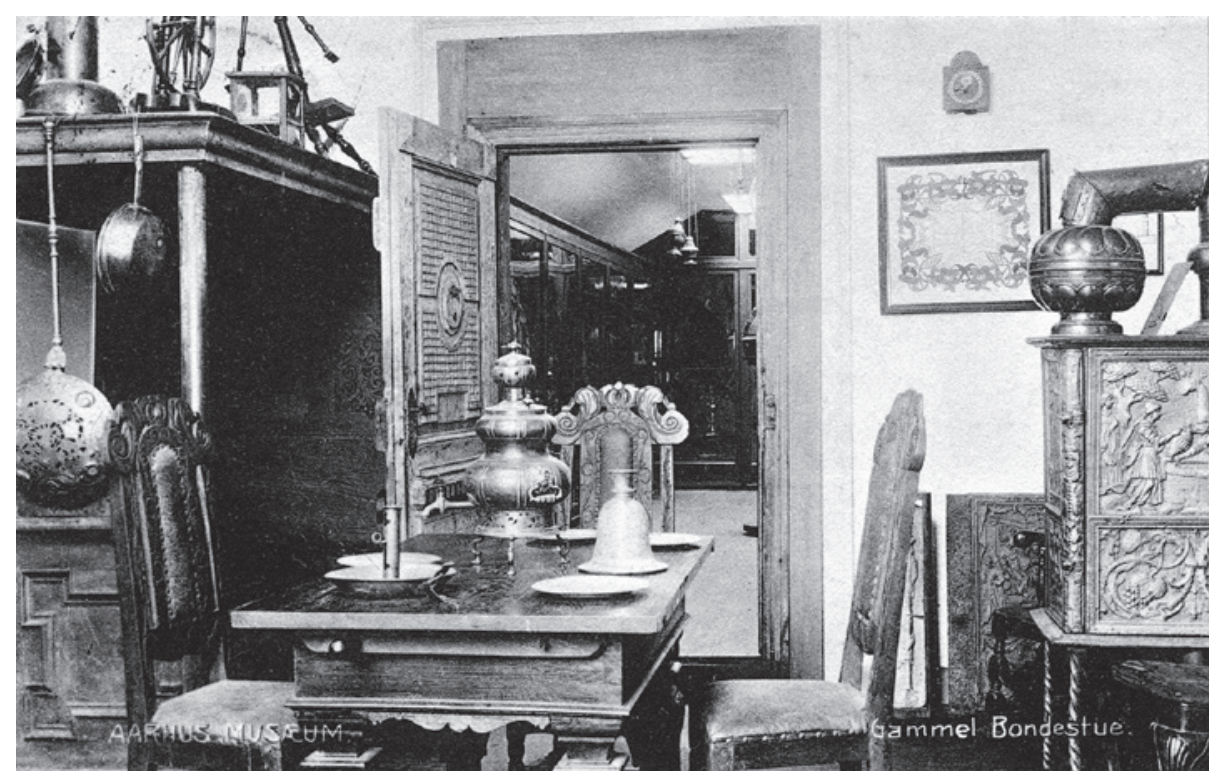

Fig. 10. Samlingerne fra nyere tid på museumsbygningens loft o. 1905. I forgrunden er indrettet en bondestue. Bemærk de skrå vægge i baggrunden. - Lokalhistorisk Samling. Århus Kommunes Biblioteker.

The modern collections in the loft of the museum building around 1905. A peasant's room is set up in the front. Note the sloping walls at the back.

Åbningstiden blev udvidet med onsdag eftermiddag, og interessen var stor. Det årlige besøgstal steg fra 17.561 personer i 1892 til 23.150 i 1901 for yderligere at stige, heraf udgjorde skole- og højskoleklasser nogle tusinder. ${ }^{116}$ Efter den tids forhold var det en meget pæn søgning.

Det omfattende udgravnings- og indsamlingsarbejde fortsatte. Stedse havde man været meget opmærksom på at skaffe så nøjagtige fundoplysninger som muligt. Til dem, der indsendte oldsager eller indberettede fund, blev der sendt et spørgeskema med 22 punkter. Museet havde en række faste kontakter flere steder, der gjorde meget for at skaffe oldsager.

Smith og Reeh påbegyndte Herredsundersøgelsen af Ning herred for Nationalmuseet. ${ }^{117}$ Herredsundersøgelserne, der var blevet sat i værk af Worsaae, havde til formål at få alle bevaringsværdige oldtidsminder registrerede. Det var ret sjældent, at andre end Nationalmuseets faste stab blev betroet at foretage disse undersøgelser.

Det blev nødvendigt at foretage en prioritering i indsamlingen. Oldsager blev fra starten vægtet højest. ${ }^{118}$ Nyere sager havde ikke den samme interesse. Museet var dog opmærksom på indsamling af historiske ting fra Århus, bl.a. arkivalier og fælles udstyr fra lavene. Under indtryk af stram 
$ø$ konomi og stærkt stigende priser på oldsager begrænsedes købene af stenaldersager, som der efterhånden var temmelig mange af, og man holdt op med at avertere efter oldsager. ${ }^{119}$ Museet var desuden i besiddelse af en etnografisk samling, men den havde og vedblev med at have laveste prioritet. $^{120}$

\section{Nationalmuseet}

Ved Herbst's fratræden i 1892 blev Oldnordisk Museum omdøbt til Nationalmuseet, og det blev delt i to afdelinger, hvoraf Sophus Müller blev direktør for 1. Afdeling, som omfattede oldtiden, antikken og de etnografiske samlinger. Det var også ham, der skulle stå for det fortsatte tilsyn med provinsmuseerne. Han kom på årligt besøg i Århus, deltog i et bestyrelsesmøde og var med til at skrive protokollen under. Nationalmuseet afregnede kontant for de oldsager, der skulle afleveres. Sophus Müller bad i adskillige tilfælde pænt, om han måtte låne sager, han skulle bruge til sin forskning. ${ }^{121}$

I modsætning til de øvrige provinsmuseer sluttede museet i Århus fuldstændig op om Sophus Müller og Nationalmuseet. På museumsmødet i Århus 1894 erklærede Smith sig tilfreds med, at Nationalmuseet skulle give tilladelse til udgravninger. Man accepterede også, at Nationalmuseet kort efter begyndte at annoncere med, at oldsager kunne indleveres direkte hertil. ${ }^{122}$

Sophus Müller opfordrede på sin side Reeh og Smith til at skrive til Aarbøger for Nordisk Oldkyndighed og Historie om museets udgravninger af stenaldergrave. Bestyrelsen i Århus besluttede at skaffe særtryk til medlemmerne. ${ }^{123}$

\section{Møntsamlingen}

Indsamling og opkøb af ældre mønter og medaljer såvel danske som udenlandske havde altid haft stor interesse for museet. Reeh gjorde så stor en indsats for møntsamlingen, at det er på sin plads at behandle den samlet her.

Efter Erslevs afrejse havde Simesen stået for en ordning og registrering af møntsamlingen. ${ }^{124}$ Samlingen fik som nævnt et væsentligt tilskud med Chr. Kjers møntsamling, men en testamentarisk gave modtaget 1883 fra boet efter cand.phil. A.B. Freund var ret enestående. Den bestod af ca. 4.500 mønter, mest af kobber, men enkelte af guld og sølv. Mønterne var især antikke fra Spanien, Gallien, Italien og Grækenland. Medaljerne var især danske, svenske, pavelige og russiske. ${ }^{125}$

Reeh førte en minutiøs tilvækstliste og sendte talrige forespørgsler til P. Hauberg på Den kgl. Mønt- og Medaille-Samling på Nationalmuseet. 
Han bad om råd om, hvorvidt mønter skulle erhverves til afdelingen, og om hvorvidt mønter skulle udleveres til København mod dubletter eller kontant afregning. ${ }^{126}$

\section{Skisma}

Reeh, der foruden at være overretssagfører, var redaktionssekretær på Jyllands-Posten og passede alt af betydning på museet, meddelte uden varsel i februar 1899, at han nedlagde alle tillidsposter, han havde for museet, og udmeldte sig af selskabet. Bestyrelsen kunne ikke konstatere nogen uregelmæssigheder. ${ }^{127}$ Sophus Müller skrev: »Det er høist sørgeligt, at see hans hele Stilling og Liv falde fra hinanden «. ${ }^{128}$ Året efter døde Reeh, netop fyldt 50.

Apoteker C.M.Chr. Reimers (1845-1902) lod sig overtale til at overtage formandsposten, men kun som konstitueret. Den næste ordinært valgte formand i $1900 \mathrm{blev}$ den tidligere omtalte grosserer, fabrikant og tysk konsul F.C.V. Ollendorff (1847-1918) (fig. 11). Han var en dygtig forretningsmand og amatørarkæolog, men han havde næppe sans for formidling og for at drive et museum med bredere folkelig opbakning. Inden for museumsverdenen lagde Ollendorff sig meget tæt op ad Sophus Müller og har næppe troet på, at nye ideer lod sig realisere. ${ }^{129}$

Fig. 11. F.C.V. Ollendorff, købmand, grosserer, fabrikant og tysk konsul. Han var amatørarkæolog, men overlod sin samling til Århus-museet, hvor han blev formand i 1900 , kort tid efter han var trådt ind i bestyrelsen. Han tilhørte Sophus Müllers fløj inden for museumsverdenen og fulgte ham i tykt og tyndt. - Lokalhistorisk Samling. Århus Kommunes Biblioteker.

F.C.V. Ollendorff - a merchant, manufacturer and German consul - was an amateur archaeologist. He left his collection to the Århus museum, of which he became chairman in 1900 , shortly after he had joined the committee. He belonged to the Sophus Müller wing within the museum world and followed Müller through thick and thin.

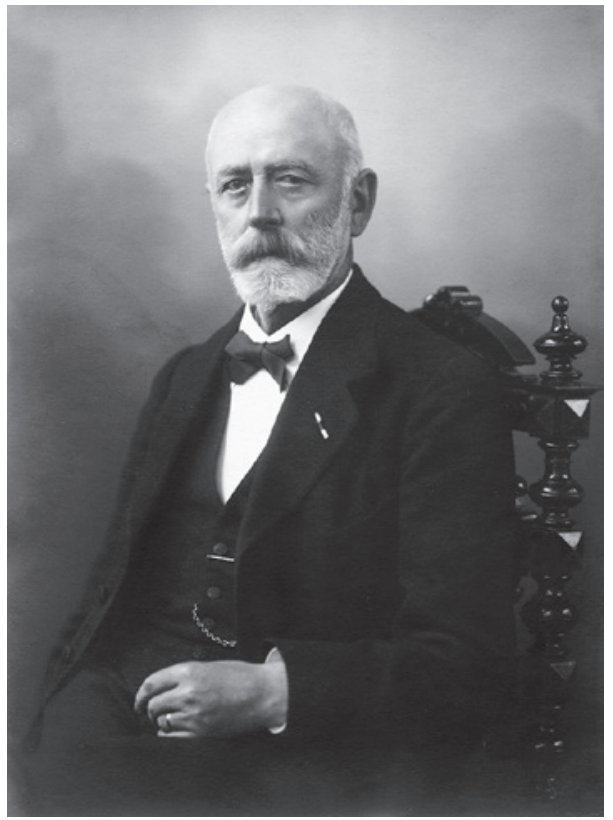




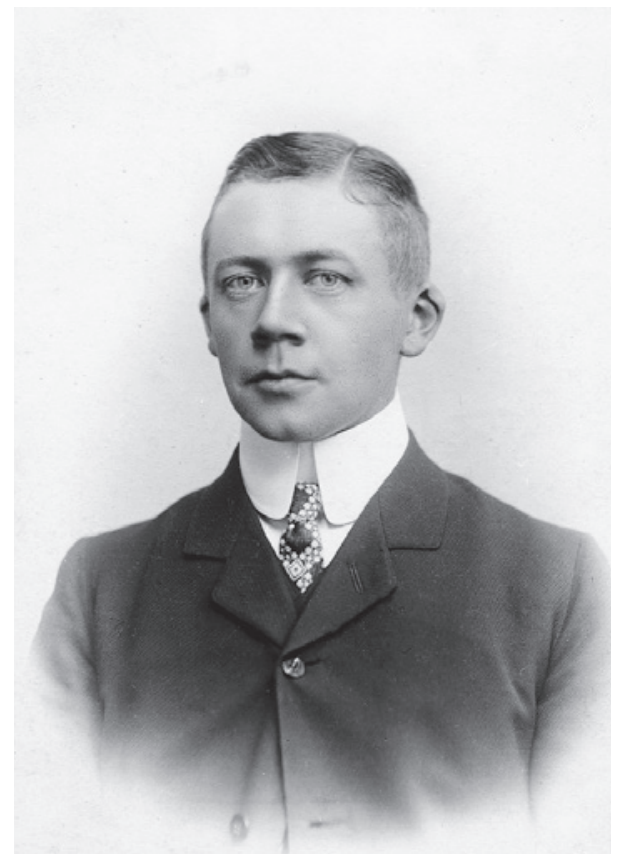

Fig. 12. Peter Holm, lærer og translatør i engelsk. Rundet af en århusiansk håndværkerslægt viede han sit liv til bevarelsen af gamle købstadsmiljøer, der ellers ville være gået tabt med industrialiseringen. - Lokalhistorisk Samling. Århus Kommunes Biblioteker.

Peter Holm, a teacher and translator of English. He came from an old Århus family of craftsmen and devoted himself to the preservation of old town settings which would have otherwise been lost due to industrialisation.

Økonomien var fra starten stram. F.eks. afslog man i 1901 at købe en etnografisk samling og en samling af inventar fra 1700-tallet, ${ }^{130}$ og i 1905 blev truffet principbeslutning om, at samlingen kun skulle omfatte oldtiden, og at der fra senere tider kun skulle indsamles genstande med tilknytning til Århus og nærmeste omegn. ${ }^{131}$

Som kuriositet kan nævnes, at byrådet 1906-08 havde udpeget den legendariske redaktør og folketingsmand Peter Sabro (1867-1913) som sin repræsentant. Han dukkede ikke op til nogen af de møder, hvortil han blev tilsagt. Langt større interesse knytter der sig til, at en af tidens førende arkitekter, Hack Kampmann (1856-1920), i 1896 var blevet medlem af bestyrelsen. Dermed kom interessen for gamle bygninger ind i bestyrelsen. ${ }^{132}$ De nye vinde kom til at blæse stærkt, da bestyrelsen i 1907 opfordrede lærer og translatør P. Holm (1873-1950) til at indtræede (fig. 12). ${ }^{133} \mathrm{P}$. Holm havde vist nok første gang kontaktet den historiske afdeling i 1898, hvor han gjorde opmærksom på, at to malerier af N.C. Holm kunne fås, ${ }^{134}$ og han var ikke ukendt i historiske kredse, da han kom med i bestyrelsen for museet i Århus. Her tog han straks arbejdet med bevarelse af gamle bygninger op og begyndte at undersøge mulighederne for at overtage $M$. Bechs gårds sidefløj ud til Badstuegade, sideløbende med at han indgik i det daglige arbejde i museet og påtog sig at overføre de gamle lavsarkivalier fra Arhus til Landsarkivet i Viborg. ${ }^{135}$ 


\section{Borgmestergården}

Århus skulle være vært for Landsudstillingen i 1909, og i den forbindelse viste sig nye muligheder for at arbejde med gamle bygninger. P. Holm var kommet med i et udvalg, der skulle forberede en lokalhistorisk sektion på udstillingen, og det viste sig samtidig, at Den Secherske gård fra 1500-tallet på hjørnet af Lille Torv og Immervad var solgt til nedrivning. Da sektionen kunne erhverve den for $2.000 \mathrm{kr}$., slog man til. Holm bad om museets støtte; formanden var imod, mens Hack Kampmann sluttede op om planerne. Det endte med, at museet bevilgede $1.000 \mathrm{kr}$. mod at komme til at eje gården, når udstillingen var forbi. ${ }^{136}$ Museet udlånte en del møbler, billeder, gamle ovne og andet inventar til udstilling i den gamle gård, der blev genopført på udstillingspladsen omkring Strandvejen. Museet henstillede, at der ved genopførelsen blev taget hensyn til, at museet senere kunne få den stillet op et andet sted. P. Holm indrettede en udstilling i bygningen, der blev meget rost.

Efter udstillingen var der et udbredt ønske om at bevare »Den gamle Borgmestergaard «, som den nu kaldtes, men uanset hvordan tingene blev vejet og drejet, så havde museet ikke råd til at stå for en genopførelse. Formanden var også indædt modstander. Han ville i givet fald kun være med til at bevare porthammeren med indskrift og årstal. Hvis resten skulle bevares, skulle det være som pindebrænde. ${ }^{137}$ Århus Stiftstidende talte varmt for sagen ${ }^{138}$ og der dannedes en komité med det formål at bevare Den gamle Borgmestergaard. P. Holm indtrådte i komiteen og udtrådte i vinteren 1910 af museets bestyrelse. Meningsforskellene til trods blev han ledsaget af en takkeskrivelse. ${ }^{139}$ Andre medlemmer af komiteen var overretssagfører Chr. Kjer, museets tidligere formand, Hack Kampmann og skoledirektør Chr. Buur (1864-1941), der senere skulle blive formand for museet. Komiteen købte gården af museet i 1911, og den blev genopført i Det jyske Haveselskabs Have. Det var lykkedes at indsamle de 30.000 kr., der var nødvendige til flytningen og indretningen af gården. Forudsætningen for et statstilskud på $10.000 \mathrm{kr}$. var, at gården blev stillet under tilsyn af Nationalmuseets 2. Afdeling (middelalder og nyere tid) som en selvejende institution.

Da Den gamle Borgmestergaard i 1915 søgte staten om et årligt driftstilskud på 1.500 kr. bl.a. til aflønning af en driftsleder, spurgte Kirke- og Undervisningsministeriet bestyrelsen for Aarhus Museums historiske Afdeling og Nationalmuseet, om der kunne skabes en naturlig orden mellem de to historiske museer i Århus. Formanden for Aarhus Museums historiske Afdeling, Ollendorff, frygtede konkurrence i modsætning til et flertal i bestyrelsen med Ejler Haugsted i spidsen, der hilste det nye museum velkommen. Ejler Haugsted (1875-1959) var trådt ind i bestyrelsen i 1909 og fik senere meget stor betydning for museet. 
Responcaerne fra Nationalmuseet siger en del om Sophus Müller og lederen af afdelingen for middelalder og nyere tid, historikeren, dr. phil. M. Mackeprang (1869-1959). Han gav sagen en varm anbefaling. Der kunne ikke være tale om skade for de øvrige museer. Tværtimod. En driftsleder burde ansættes, og Nationalmuseets 2. Afdeling burde føre tilsyn. Sophus Müller var af den stik modsatte opfattelse. Der ville blive konkurrence med de eksisterende museer. Udgifterne for statskassen ville blive alt for store, og frivillighedsprincippet burde bevares. Interiører fra nyere tid var lette at skaffe og behøvede ikke statsstøtte. I øvrigt burde gamle bygninger bevares på deres oprindelige plads. »Thi det gaar med Lethed af sig selv, fordi man derved opnaar en Underholdningsinstitution, som har saa megen Tiltrækning for det brede Lag: Disse halvt ægte, halvt falske Bygninger, med efterlignede Interiører med allevegnefra sammenstykkede Opstillinger af Sager helt ned til vore Forældres Tid. Det er morsomt at se paa, det tilegnes uden Forudsætninger og uden at anstrenge Øje og Tanke, og byder en kærkommen Underholdning for den store Mængde. Byen faar et Etablissement, som alle gærne virker med til, og som er let at drive. Det synes rigtignok, at Staten ikke kan give Driftsmidler til saadant«. For ham svarede Holms museumsvirksomhed til en historisk roman og var ikke videnskab. ${ }^{140}$

\section{Krise}

Tilbage i Aarhus Museums historiske Afdeling var forholdene nærmest fortvivlende. Under og efter 1. verdenskrig var der dyrtid, og det mærkede museet også. Årsbudgettet var skrumpet ind fra ca. 2.000 kr. i 1890 'erne til ca. $1.500 \mathrm{kr}$. Amterne havde således inddraget deres tilskud. De $1.500 \mathrm{kr}$. skulle fordeles mellem oldsagssamlingen, møntsamlingen og samlingen fra historisk tid og bestride udgifter til undersøgelser, udgravninger, forøgelse af inventar samt administration og repræsentation. Bygningen trængte hårdt til en gennemgribende istandsættelse. F.eks. kom der ofte til at stå vand i kældrene, og der var ikke råd til at lade dem opvarme. ${ }^{141}$ Der fremkom forslag om at sælge bygningerne og grunden for at anvende salgssummen til at opføre nye museumsbygninger et andet sted. ${ }^{142}$

Det turde være indlysende, at et samarbejde med "Borgmestergården" var påkrævet. Udover stram økonomi havde den historiske afdeling opmagasineret mange værdifulde genstande, som der ikke var plads til i udstillingerne.

Ollendorff døde i 1918; ny formand blev lektor ved katedralskolen, cand.theol. F.C. Lorentzen. Inden for museumsverdenen tilhørte han samme fløj som Sophus Müller og Ollendorff. 


\section{Provinsmuseum med store forventninger}

Efter Sophus Müllers fratræden i 1921 blev M. Mackeprang direktør for begge Nationalmuseets afdelinger. Næsten fra den ene dag til den anden skete der en ændring i Nationalmuseets forhold til provinsmuseerne. Han sendte en række skrivelser med henstilling til samarbejde mellem Aarhus Museums historiske Afdeling og Borgmestergaarden. Mackeprang krævede bl.a., at der blev udarbejdet en fælles registrering af sager, der hidrørte fra Århus' historie. Det kunne formanden, Lorentzen, godt gå med til, men han kunne ikke acceptere, det blev starten til et tættere samarbejde med Borgmestergården. Da de øvrige fire bestyrelsesmedlemmer ønskede dette, trådte han ud af bestyrelsen. Undervisningsministeriet stillede øget tilskud i udsigt, hvis der kom et tættere samarbejde med Borgmestergården. ${ }^{143}$ I 1924 sendtes derfor en officiel henvendelse til Den Gamle By, som dette museum da kommer til at hedde, om genstandene fra middelalder og nyere tid måtte opstilles i den såkaldte Aalborggård. (Et stort bygningskompleks fra Aalborg, der netop var blevet genopført i Den Gamle By.) En aftale kunne endelig indgåes to år efter. Den indebar, at Aarhus Museums historiske Afdeling fortsat ejede disse genstande og skulle dække omkostningerne ved dem, men have andel af Den Gamle Bys entreindtægter. Inspektøren for Den Gamle By, P. Holm, skulle stå for disse samlinger, og ministeriet krævede, han genindtrådte i bestyrelsen for det historiske museum. ${ }^{144}$ Overenskomsten blev underskrevet i januar 1926. P. Holm og Ejler Haugsted fik hver bevilget 400 kr. årligt som vederlag for at forestå det praktiske arbejde med samlingerne. ${ }^{145}$

De etnografiske sager blev overladt til Naturhistorisk Museum. ${ }^{146}$ Herefter var kun oldtiden og møntsamlingen tilbage i museumsbygningen, der godt kunne trænge til den istandsættelse, der da blev påbegyndt. ${ }^{147}$

\section{Ejler Haugsted}

Formand for bestyrelsen fra 1922 var skoledirektør Chr. Buur, og Ejler Haugsted blev næstformand (fig. 13). Han trådte nu mere og mere frem som den, der skulle tegne museet de næste mange år. Som cand.mag. i historie, engelsk og latin var han ansat som bibliotekar på Statsbiblioteket, hvor han var optaget af almindeligt biblioteksarbejde. Han var med i bestyrelsen for Historisk Samfund for Aarhus Stift så godt som fra starten og 1908-52 redaktør af dets årbog og ansvarlig for dets øvrige udgivelser. 1916-52 var han også formand. Årbøgerne benyttede han til at offentliggøre en lang række af de resultater, der blev opnået på museet. Der er både artikler om udgravninger og om tilvæksten ${ }^{148}$ men de er dog ikke systematiske. Han var også påpasselig med at give aviserne besked om, hvad der 


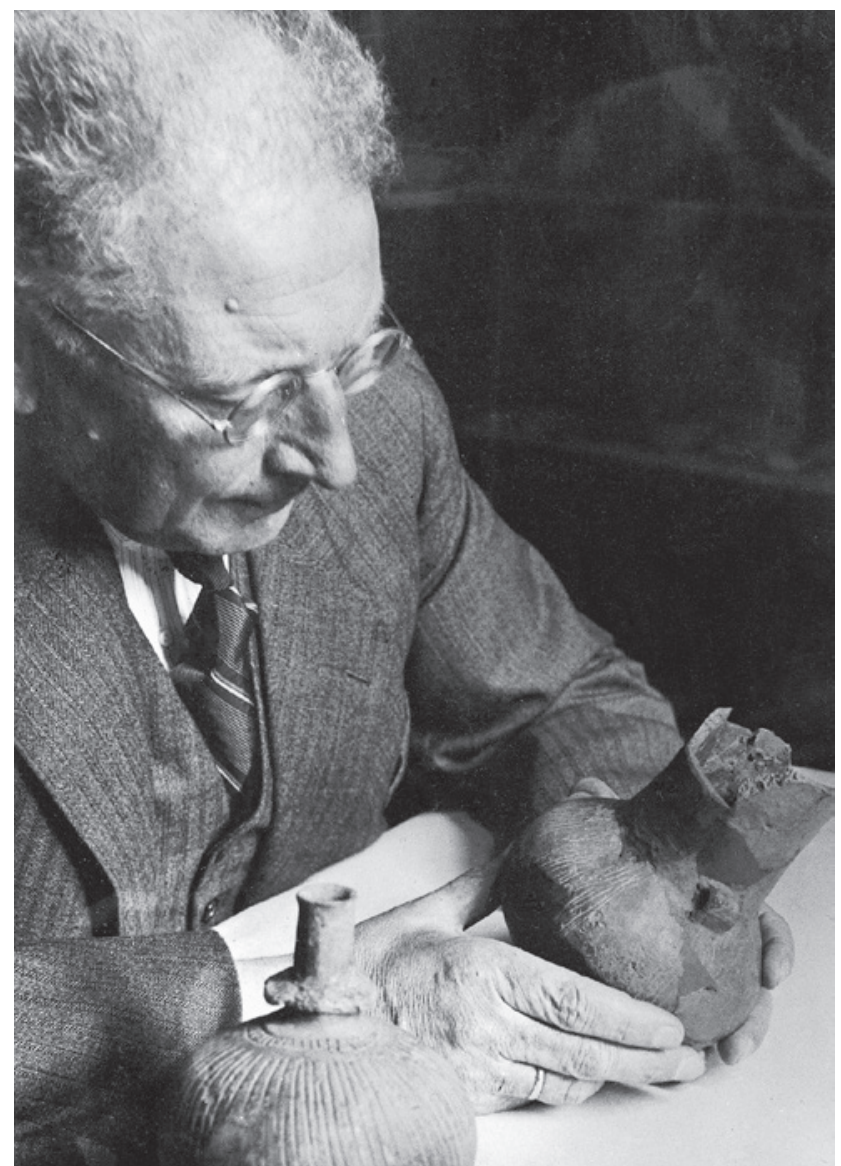

Fig. 13. Ejler Haugsted i gang med at studere keramik fra ældre bondestenalder. Han var egentlig ansvarlig for

Århus-museets samlinger fra middelalder og nyere tid, men det var som tilsynsførende for oldsagssamlingen han fik størst betydning. - Privateje.

Ejler Haugsted studying pottery from the early Stone Age. He was in fact responsible for the medieval and modern collections in the Århus museum, but as the supervisor of the prehistoric collection he had a strong influence on the archaeological work of the museum.

foregik. Endvidere leverede han en række bidrag til bogværket »Danske Slotte og Herregaarde« og var en af hovedkræfterne bag »Aarhus gennem Tiderne« - et stort anlagt værk om Århus bys historie.

Haugsted kombinerede således en stor arbejdsevne med stor faglig dygtighed, og der var nok at tage fat på. Foruden udgravningerne, skulle samlingen nyopstilles. Den nye opstilling af oldsagerne var endelig færdig i 1935 og fik gode anmeldelser i pressen (fig. 14). ${ }^{149}$

Landsretssagfører Andreas Christensen blev formand i 1927 og var det lige til sin død i 1953. Han kunne i 1942 med glæde fortælle Haugsted, at dennes årlige honorar var sat op med $800 \mathrm{kr}^{150}$ Offentlige bevillinger og private gaver forøgedes således en del. Det var ikke uden betydning, at Otto Mønsted og Hustrus Fond i 1934 tilstod Den historiske Afdeling og Kunstafdelingen et legat på 50.000 kr. til deling. P. Holm udtrådte af bestyrelsen i 1946 og blev erstattet af sin afløser som direktør for Den Gamle By, dr.phil. Helge Søgaard (1907-90). 

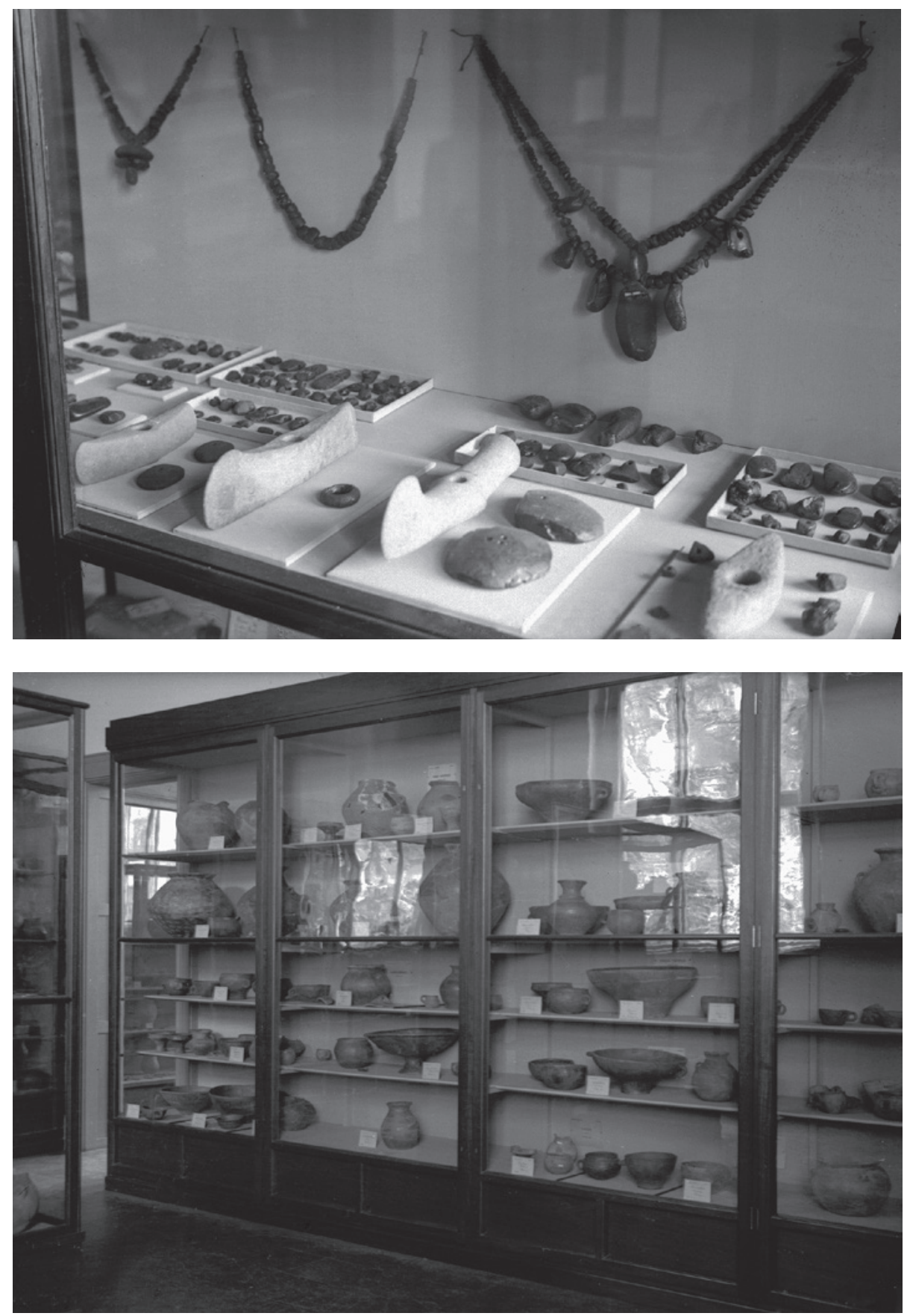

Fig. 14. Fra udstillingen efter den i begyndelsen af 30'erne var blevet genopstillet af E. Haugsted. - Lokalhistorisk Samling. Århus Kommunes Biblioteker.

Part of the collection after the display had been re-made by E. Haugsted in the 1930s. 
Museet mærkede imidlertid ikke den samme begejstrede tilslutning som i perioder i det foregående århundrede. De besøgende svigtede ganske, selv om der var gratis adgang. ${ }^{151}$ For at afhjælpe det blev Haugsted engageret til at lave et katalog over Den historiske Afdeling. ${ }^{152}$

\section{"Universitetsmuseum»}

Da det stod klart, at Århus var blevet hovedbyen i provinsen og landets vigtigste by efter København, begyndte man også på museet at omdefinere sin rolle. ${ }^{153}$ Allerede i 1921, da mulighederne for etableringen af et universitet i Jylland blev sonderet, erklærede Den historiske Afdeling, at den ville kunne få betydning for en evt. kommende universitetsundervisning. ${ }^{154}$ Med stolthed noterede bestyrelsen i 1939, at afdøde professor Plesner et par år forinden havde gennemgået samlingerne med et hold ældre studerende, og erklærede: »Museet er hovedsamling for Oldsager i Jylland og Aarhus Universitets forhistoriske Studiesamling ${ }^{155}$

Under 2. verdenskrig kom der skred i udviklingen. Da blev fhv. justitsminister og senere borgmester i Århus, Svend Unmack Larsen (18931965), medlem af bestyrelsen, og han foreslog et nærmere samarbejde med universitetet. I første omgang skete det ved, at bestyrelsen optog docent, senere professor i historie, A. Afzelius (1905-57) som medlem. ${ }^{156}$ I en række avisartikler gjorde han opmærksom på, at kunstafdelingens mange gipsafstøbninger af klassisk kunst ville være et fund for et universitet og på, at museernes pladsforhold var helt utilstrækkelige. ${ }^{157}$

Århus kommune gik nu meget aktivt ind i museumssagen og gav store tilskud. Planen var, at der skulle opføres nye bygninger både til kunstafdelingen og Den historiske Afdeling i Vennelystparken. ${ }^{158}$

I 1949 blev P.J. Riis udnævnt til professor i klassisk arkæologi og dr.phil. P.V. Glob (1911-84) til professor i forhistorisk arkæologi. Kunstafdelingens meget pladskrævende gipsafstøbninger af klassiske skulpturer blev da overtaget af universitetet og kom til at indgå i klassisk arkæologis studiesamling. Derved blev der også bedre plads i den gamle museumsbygning til oldsagssamlingen, og den blev P.V. Glob også leder af.

\section{Forhistorisk Museum}

Bestyrelsen fortsatte som hidtil, men P.V. Glob deltog i møderne. Det første par år var Haugsted også fortsat ansat. Med ansættelsen af en fast faguddannet leder undergik museet så væsentlige ændringer, at de tydeligst ses ved at trække nogle hovedpunkter op. Samtidig blev det økonomiske grundlag fundamentalt ændret ved øgede tilskud fra stat og kommune, og der blev også skaffet andre midler, ligesom Kunstmuseet afstod nogle af 
sine lokaler. Det besluttedes at specialisere sig i forhistorisk arkæologi og etnografi, hvilket fik betydelige konsekvenser. Museets navn blev således ændret til Forhistorisk Museum, og opbygningen af en egentlig etnografisk samling blev påbegyndt. Til gengæld gav museet afkald på ejendomsretten til samlingerne fra middelalder og nyere tid, der var deponerede i Den Gamle By, og holdt op med at betale til dem. Møntsamlingen blev ligeledes afleveret til Den Gamle By.

På den anden side blev engagementet inden for specialområderne tilsvarende udvidet og styrket, og museet fik straks en førerstilling på disse felter. Det blev således centralmuseum for forhistorisk arkæologi for hele Jylland. Det opnåede status af landsdelsmuseum, og det blev universitetsmuseum. Denne betegnelse var en forudsætning for at få en professor som leder. Det var utænkeligt for et almindeligt lokalmuseum. ${ }^{159}$

Medarbejderstaben udvidedes i et omfang, der blot få år tidligere ville have været utænkeligt. I $1950 \mathrm{blev}$ ansat en fuldtids konservator og yderligere en inspektør foruden administrativt personale. I 1959 bestod den videnskabelige medarbejderstab af fem museumsinspektører, mens en adjunkt i etnografi ved universitetet tog sig af den etnografiske samling.

Ekspeditionerne til først Bahrain og siden til andre lande langs Den arabiske Golf blev startet. På disse blev der foretaget både omfattende arkæologiske udgravninger og etnografiske indsamlinger. Det var utænkeligt, at et almindeligt provinsmuseum kunne have magtet denne opgave.

I første omgang gav museet afkald på arealer i Vennelystparken mod at få lovning på hele museumsbygningen, når Kunstmuseet flyttede, men planerne for at flytte museet til Moesgård begyndte mere og mere at tage form. P.V. Glob blev opfordret til at søge embedet som rigsantikvar, og han lagde ikke skjul på, at han underhånden havde fået at vide, at planerne ville blive fremmet, såfremt han overtog embedet.

P.V. Glob tiltrådte som rigsantikvar 1. april 1961. Den 19. marts samme år havde museet fejret sit hundredårs-jubilæum "passende nok« med en etnografisk udstilling om det moderne Indien. ${ }^{160}$

\section{NOTER:}

Forkortelser:

Aa.St.: Aarhus Stiftstidende.

Hvor intet andet anføres, findes arkivalier i museets arkiv på Moesgård Museum.

1. Rasmussen 1979, s. $7 \mathrm{ff}$.

2. Thomsen 1963, s. 634.

3. Jensen 1992, s. 46 og note 14, s. 388. Tankerne om folkeopdragelse blev især udviklet af den tyske filosof J.G. Fichte, og hans landsmand Novalis udviklede tanker om genopdragelse til en gylden, svunden fortid.

4. Nielsen 2001, s. 111. 
5. Müller 1912, s. 181ff. Mackeprang 1912, s. 157.

6. Street-Jensen 1988. Jensen 1988a og 1992.

7. Wiell 2000.

8. Rubin 1892, s. $26 f f$.

9. Forchhammer 1866.

10. Lundbæk 1967a, s. 15.

11. Dette afsnit bygger især på Kjær 1980b, hvor der også er en mere detaljeret gennemgang af museets tidligste historie.

12. Forhandlingsprotokol 1861-89/Tilvækstprotokol. Nr. 1-1499.

13. $» B r e v$ fra en Rejsende til den $» B r l g$. Tid««. Aa.St. 14/12 1861.

14. Jensen 1993, s. 78ff.

15. Kjær 1980a, s. 372-73.

16. Dansk biografisk Haandleksikon.

17. Dybdahl 1959, s. 7.

18. Sejr 1961-62.

19. Kjær 1980b, s. 52-53.

20. Lundbæk 1967a, s. 30.

21. Brev fra Aarhus Kommunalbestyrelse, dat. 24/10 1861. Arkivsager 1861-78.

22. Kjær 1980b, s. 47ff. Bestyrelsesmøde 30/9 1862. Forhandlingsprotokol 1861-89/Tilvækstprotokol. Nr. 1-1499.

23. Aa.St. $15 / 51861$.

24. Jvf. Lassen 1990, s. 10. Tilsyneladende er der mange flere annoncer fra og notitser om museet i Århus Stiftstidende, end der er registrerede på Sejrs sedler på Statsbiblioteket/ Erhvervsarkivet.

25. Aa.St. 3/2 1863.

26. Bestyrelsesmøde 26/3 1861. Forhandlingsprotokol 1861-89/Tilvækstprotokol. Nr. 11499. Eriksen 1990.

27. 26/4 1861. Forhandlingsprotokol 1861-89/Tilvækstprotokol. Nr. 1-1499. Haugsted 1939, s. 71-72.

28. Jensen 1992, s. 119.

29. Kjær 1988.

30. Kjær 1980b, s. 57ff.

31. Wiell 1997, s. 132.

32. $28 / 4$ 1863. Forhandlingsprotokol 1861-89/Tilvækstprotokol. Nr. 1-1499.

33. Wiell 1997 og 2000.

34. Kjær 1980b, s. $63 \mathrm{ff}$.

35. Kjær 1980a, s. 371.

36. Aa.St. 5/7 1870 .

37. Aa.St. $19 / 41872$.

38. 9/8 og 11/10 1869. Forhandlingsprotokol 1861-89/Tilvækstprotokol. Nr. 1-1499.

39. Han ejede bygården nr. 907 i Rosensgade i Århus, men boede for det meste forskellige andre steder. Da Selskabet blev stiftet, opholdt han sig tilsyneladende på Bygholm.

40. 8/11 1869. Forhandlingsprotokol 1861-89/Tilvækstprotokol. Nr. 1-1499. Diverse svarskrivelser. Arkivsager 1861-78.

41. 4 og 19/1 1871. Forhandlingsprotokol 1861-89/Tilvækstprotokol. Nr. 1-1499. Arkivsager 1861-78.

42. $25 / 4$ og 21/6 1870. Forhandlingsprotokol 1861-89/Tilvækstprotokol. Nr. 1-1499. Aa. St. $5 / 71870$.

43. Aa. St. 2/7 1870 og 19/4 1872. Det drejede sig om 850 genstande fra stenalderen, 300 fra bronzealderen, over 100 fra jernalderen og over 200 fra middelalderen og nyere tid. Lunds og Simesens rundskrivelse fra 1871. Arkivsager 1861-78. 
44. Wiell 1997, s. 166ff, s. 214.

45. 3/1 1870. Forhandlingsprotokol 1861-89/Tilvækstprotokol. Nr. 1-1499.

46. 11/10 1869. Forhandlingsprotokol 1861-89/Tilvækstprotokol. Nr. 1-1499. Aa.St. 5/7 1870.

47. P.B. Obel til bestyrelsen 27/12 1872. Arkivsager 1861-78.

48. Kjær 1980a, s. 385-86.

49. Jeppesen 2001. Dalgas 14/8 1861. Arkivsager 1861-78.

50. Breve fra Sarauw, dat. 30/10 og 16/11 1899. Arkivsager 1899-1900.

51. 28/12 1872. Forhandlingsprotokol 1861-89/Tilvækstprotokol. Nr. 1-1499.

52.. Worsaae 14/1 1873. Arkivsager 1861-78.

53. Boye til Lund 16/6 1874. Arkivsager 1861-78.

54. Mørk til Lund. 23/6 1874. Arkivsager 1861-74.

55. Aa.St. 30/7 1874.

56. $22 / 8$ og 7/12 1874. Forhandlingsprotokol 1861-89/Tilvækstprotokol. Nr.1-1499. Fortegnelse over Dem til hvem Selsk. for den hist.-antiqu. Samling i Aarhus tilsender Exemplarer af ॥Vejledning til Udgravning af Oldsager og deres foreløbige Behandling«. Arkivsager 1861-78. På Moesgård Museum findes stadig et restoplag.

57. 22/8 1874. Forhandlingsprotokol 1861-89/Tilvækstprotokol Nr.1-1499.

58. Aa. St. 23/2 1872. Lundbæk 1967b, s. 71.

59. Lundbæk 1967a, s. 73ff. Haugsted 1941, s. 256.

60. Lundbæk 1967b, s. 73 f.

61. A. Weis til stadsingeniør Obel 4/1 1875. Arkivsager 1861-78.

62. Lundbæk 1967a, s. 33ff, Lundbæk 1967b, s. 71ff.

63. 15/2 1876. Forhandlingsprotokol 1861-89/Tilvækstprotokol. Nr. 1-1499.

64. Fællesudvalget for Bestyrelsen af Raadhusbygningen til Bestyrelsen for Oldsamlingen i Aarhus. 29/7 1877. Arkivsager 1861-78. Aa. St. 12/10 1877.

65. Museums(tilvækst)protokol. Nr. 1500-5496.

66. Diverse kvitteringer og breve. Arkivsager 1882-87.

67. Lund til Worsaae 26/4 1878. Nationalmuseets arkiv. Middelalder og Nyere. Museumshistorisk arkiv. Breve til Worsaae.

68. Aa.St. 19/7 1879.

69. Aa.St. $1 / 121879$.

70. 27/3 1883. Forhandlingsprotokol 1861-89/Tilvækstprotokol. Nr.1-1499.

71. Lund 23/7 1885. Arkivsager 1882-87. 16/4 1886. Forhandlingsprotokol 1861-89/ Tilvækstprotokol. Nr. 1-1499.

72. Borgere i byens råd, s. 117. Kopier af breve fra Kjer til Regenburg, dat. 2/12 1886, 20/8 1887, 31/10 1888, 11/5 og 14/6 1889, til Sophus Müller 19/7 1886 og til kaptajn Smith 4/9 1889. Kopibog 1885-92. F.eks. Cirkulæreskrivelser 1/10 1889. Arkivsager 1889. 28/ 2 1890. Arkivsager 1890.

73. Kopi af brev fra Kjer til Japetus Steenstrup, dat. 1/8 1887. Kopibog 1885-92.

74.. Kopi af brev fra Kjer til Henry Petersen, dat. 17/2 1892. Kopibog 1885-92.

75. Kopi af brev fra Kjer til Sophus Müller, dat. 26/8 1886. Kopibog 1885-92.

76. 18/8 1886. Forhandlingsprotokol 1861-89/Tilvækstprotokol. Nr. 1-1499.

77. Frisch 20/6 1887.

78. Larsen 1935.

79. Larsen 1935, s. 23. Jvf. Nielsen 2001, s. 151.

80. Worsaae 17/5 1871. Arkivsager 1861-78. Kjær 1988, s. 193.

81. Brøndsted 1963, s. 27.

82. Holm 1950, s. 13.

83. Jensen 1988 b, s. 52

84. Becker 1979, s. 73-74. Når tanken ikke blev realiseret i Sophus Müllers embedsperiode, 
skyldtes det vist nok, at der opstod personlige uoverensstemmelser mellem ledende kredse på Nationalmuseet og universitetet.

85. Jensen 1988b, s. 52.

86. Bidstrup 1976, s. $98 \mathrm{ff}$.

87. Kopier af breve fra Kjer til Smith og Frisch, dat. 17/7 1886, til Sophus Müller, dat. 3 og 4/9 1886. Kopibog 1885-92. Udateret svar fra Müller. Arkivsager 1882-87. Kaptajn A.P. Madsen (1822-1911) var meget benyttet som tegner af Oldnordisk Museum og betragtedes af samtiden som en autoritet inden for arkæologi.

88. Sophus Müller 20/8 1886. Arkivsager 1882-87.

89. Kopi af breve fra Kjer til Müller, dat. 7/9, 28/10 og 30/10 1886, 30/6 1887. Kopibog 1885-92.

90. Nielsen 1989, s. 195f., 2001, s. 117ff.

91. Kopier af breve fra Kjer til Barfod, Aalborg, dat. 10/2 og 18/5 1887 og til Sophus Müller, dat. 18/5 1887. Kopibog 1885-92.

92. Nielsen 2001, s. $119 \mathrm{ff}$.

93. Haugsted 1941, s. 157.

94. Kopi af breve fra Kjer til Regenburg, dat. 23/5 1887, og til Sophus Müller, dat. 28/5 1887. Kopibog 1885-92.

95. Kopi af breve fra Kjer til Regenburg, dat. 31/10 1888, til Smith, dat. 25/6 1888, til Kleisdorff 30/6 1888, til indenrigsminister Ingerslev, dat. 9/4 1889, til museumsassistent Bahnson, dat. 25/4 1889. Kopibog 1885-92. Brev fra Kjer til Smith, dat. 23/6 1888. Svar, dat. 29/6 1888. Arkivsager 1888. Diverse kopier af ansøgninger. Arkivsager 1888. Kopibog 1885-92.

96. Aa.St. 12/6 1891.

97. Forhandlingsprotokol 1890-1961.

98. Kopi af brev fra Kjer til Regenburg, dat. 23/8 1890. Kopibog 1885-92.

99. Lolland-Falsters Stiftsmuseum fik en tilsvarende styring i 1891. Lassen 1990, s. 25 f.

100. Kopi af brev fra Kjer til Eschel Eschelsen, dat. 23/8 1888. Kopibog 1885-92. Svar, dat. 26/8 1888. Arkivsager 1888. Wiell 2000, s. 49. Boye 1896, s. 107.

101. Kopi af breve fra Kjer til Müller, dat. 26/8 1886 og 19/7 1887. Kopibog 1885-92. Sophus Müller 20/8 1886. Arkivsager 1882-87.

102. Se f.eks. arkivsager 1889-92 (Reeh) og arkivsager 1890 (Smith). Udgravningsprotokol 1884-96 er langt fra komplet.

103. F.eks. Sophus Müller 18/7 1888.

104. Wiell 2000, s. 75.

105. Kopi af breve fra Kjer til pastor Bach, Ry, 26/8, 1/9 og 7/9 1886, til politibetjent Jepsen, Silkeborg, dat. 28/8 og 1/9 1886. Kopibog 1885-92.

106. Boye 1896, s. 49ff. Glob 1971, s. $21 \mathrm{ff}$.

107. Worsaae 21/4 1871. Udkast til svar. Arkivsager 1861-78. 23/4 1861. Forhandlingsprotokol 1861-89/Tilvækstprotokol. Nr. 1-1499.

108. Boye til Worsaae 19/6 1871. Nationalmuseets arkiv. Middelalder og Nyere Tid. Museumshistorisk arkiv. Worsaaes breve. Stensager 2003. Andersen 1987, s. 65ff. Wiell 2000, s. 223.

109. Chr. M. Rasmussen april 1891. Arkivsager 1889-92 (Reeh). Diverse koncepter til breve. Aarhus Museums historiske Afdelings Correspondance begyndt 1888 til 1895. W. Smith.

110. Diverse. Arkivsager 1889-92 (Reeh). Chr. Møller Rasmussen 21/8 1891, Sophus Müller 14/9 1891. Arkivsager 1891. 18/5 1894, Sophus Müller 30/4 1895, Reeh til Smith 24/ 4 1894. Arkivsager 1894/95 (Reeh, Smith). Sophus Müller 25/4 1898. Arkivsager 1898/ 99. Smith til Møller Rasmussen 16/9 1891. Aarhus Museums historiske Afdelings Correspondance begyndt 1888 til 1895. W. Smith. Smith til Sophus Müller 26/4 1890, 16/5 
1890, 11/9 1891, Reeh til Sophus Müller 23/4 1898. Nationalmuseet. Oldtiden. Forhistorisk Museum. 6/5 1895. Forhandlingsprotokol 1890-1961.

111. Diverse sager. Aarhus Museums historiske Afdelings Correspondance begyndt 1888 til 1895. W. Smith.

112. Brev fra Herbst, dat. 10/9 1889, fra Sophus Müller, dat. 20/9 1889, fra Henry Petersen, dat. 22/9 1889. Kopi af brev fra Kjer til Müller, dat. 19/9 1889, til Regenburg 1/10 1889. Kopibog 1885-92.

113. 11/7 1891, 17/1 og 6/2 1894. Forhandlingsprotokol 1890-1961. Arkivsager 1889-92 (Reeh).

114. 4 kr.= 2 rd., så kontingentet var ikke hævet siden starten. Kladdeagtig medlemsfortegnelse. Arkivsager 1893-94 (Reeh og Smith).

115. Fortegnelse over Bøger tilhørende Aarhus Museums historiske Afdeling. 1893-1921. Den er konfronteret med litteraturlisterne i Sophus Müller 1897.

116. Diverse bilag til ansøgninger.

117. Reeh til Sophus Müller 29/3 1895. Nationalmuseets arkiv. Oldtiden. Forhistorisk Museum.

118. Kopi af brev fra Smith til pastor Bergsøe, Aalborg, dat. 6/2 1894. Aarhus Museums historiske Afdelings Correspondance begyndt 1888 til 1895. W. Smith.

119. 12/9 1893, 6/5 1895. Forhandlingsprotokol 1890-1961.

120. 15/11 1892. Forhandlingsprotokol 1890-1961. Sophus Müller til kaptajn Smith 29/1 1890. Arkivsager 1890. Arsberetning 1901.

121. F.eks. Sophus Müller, 21/9 1896, marts 1897. Arkivsager 1896/97-1897/98.

122. Nielsen 2001, s. 126-27.

123. A. Reeh og G.W. Smith 1891. 19/1 1892. Forhandlingsprotokol 1890-961.

124. 11/10, 8/11 og 13/12 1869, 25/4 1870. Forhandlingsprotokol 1861-89/Tilvækstprotokol. Nr. 1-1499.

125. Aa.St. 17/2 1883 og 12/10 1924. Den Freundske Mønt- og Medaillesamling. Reeh. Myntsager og nogle ældre breve 1889-92.

126. Reeh. Myntsager og nogle ældre breve 1889-92.

127. Brev fra Reeh, dat. 5/2 1899. Arkivsager 1899-1900. 7/2 og 9/2 1899. Forhandlingsprotokol 1890-1961.

128. Sophus Müller 14/2 1899. Arkivsager 1899-1900.

129. Albeck 1989, s. 51f.

130. $2 / 12$ og 30/7 1901. Arkivsager 1901-02.

131. $1 / 7$ 1905. Forhandlingsprotokol 1890-1961.

132. 27/3 1896, 13/9 1898. Forhandlingsprotokol 1890-1961.

133. 23/9 1907. Forhandlingsprotokol 1890-1961.

134. Brev fra P. Holm, dat. $27 / 4$ 1898. Arkivsager 1898/99. Det ene hed "Kavallerifægtningen ved Aarhus« er nu en central del af kunstmuseets guldaldersamling.

135. 2/1 og 18/4 1908. Forhandlingsprotokol 1890-1961.

136. 2/1 1908. Forhandlingsprotokol 1890-1961. Holm 1950, s. 15ff, Bramsen 1971, s. 11ff., Mohr 1996, s. $115 \mathrm{ff}$.

137. Holm 1950, s. 30.

138. Aa. St. 6/2 1910.

139. $27 / 1$ og 16/2 1910. Forhandlingsprotokol 1890-1961.

140. Ollendorff og Lorentzen 2/5 1915. Mackeprang 2/8 1915. Sophus Müller 20/2 og 26/4 1915. Administration og Eiendomsforhold vedrørende Aarhus Museums historiske Afdeling samt Borgmestergaarden.

141. Haugsted 1929, s. 19. 29/1 1918. Forhandlingsprotokol 1890-1961.

142. 2/9 1920. Forhandlingsprotokol 1890-1961.

143. 13/6 og 6/10 1922. Forhandlingsprotokol 1890-1961. 
144. 15/1 1924, 4/3, 7/5 og 10/10 1925. Forslag til overenskomst. Forhandlingsprotokol 1890-1961. Holm 1950, s. 116-17.

145. 22/2 1926. Forhandlingsprotokol 1890-1961.

146. 25/8 1924, jvf. 19/10 1921. Forhandlingsprotokol 1890-1961.

147. 19/10 1923. Forhandlingsprotokol 1890-1961. Jyllands-Posten 24/11 1923.

148. Se f.eks. Haugsted 1923 og 1935.

149. Aa.St. 24/11 1928. Jyllands-Posten 24/11 1928. Den midtjyske radikale Venstrepresse 24/11 1928. Aarhus Amtstidende 24/11 1928. Demokraten 24/11 1928. Aa.St. 18/4 1935. Aarhus Amtstidende 18/4 1935.

150. Museet 1942. (Diverse breve).

151. Demokraten 1/3 1945.

152. 20/12 1946. Forhandlingsprotokol 1890-1961.

153. Albeck 1989, s. 82ff.

154. 19/1 1921. Forhandlingsprotokol 1890-1961.

155. 14/7 1939. Forhandlingsprotokol 1890-1961. Johan Plesner (1896-1938), dr.phil., professor i oldtiden og middelalderens historie ved Aarhus Universitet.

156. 3/12 1943 og 23/6 1944. Forhandlingsprotokol 1890-1961.

157. Bilde 2000, s. 209 f.

158. Aa.St. 2/7 1944.

159. Thrane 2000, s. 14 .

160. Bestyrelsesmøderne fra 1949-61. Forhandlingsprotokol 1890-1961. Kjærum 1999. Ferdinand 1999. Andersen 2001.

\section{LITTERATUR OG TRYKTE KILDER:}

Albeck, Gustav 1989: Et større Danmark. Århus.

Andersen, Harald 2001: Nu bli'r der ballade. Kuml, s. 7-32.

Andersen, Niels H. 1987: Borum Eshøj. Århus Årbog 1987, s. 65-72.

Becker, C.J. 1979: Nordisk arkæologi og europæisk forhistorie. I: Povl Johs. Jensen (red.): Københavns Universitet 1479-1979. Bd. XI, s. 161-198.

Bidstrup, Knud 1976: Holger Friis forteller. København.

Bilde, Pia Guldager 2000: From Study Collection to Museum of Ancient Art: a Danish University Museum of Miditerranean Antiquities and Plaster Casts. I: John Lund and Peter Pentz (red.): Between Orient and Occident. Studies in Honour of P.J. Riis. København, s. 20931.

Boye, Vilhelm 1874: Vejledning til Udgravning af Oldsager og deres foreløbige Behandling. Århus.

Boye, Vilhelm 1896: Fund af Egekister fra Bronzealderen i Danmark. København. (Genudgivet ved Mogens Ørsnes 1986).

Bramsen, Bo 1971: Den gamle by i Arhus. Købstadsmuseets historie, topografi og liv i hverdag og fest. Århus.

Brøndsted, Johannes 1963: Hvor ved vi det fra? Politikens Danmarks Historie. Bd. I. København, s. 11-44.

Dansk biografisk Leksikon. 2. udg. Bd. I-XXVII. Red. af Povl Engelstoft. 1933-44. København.

Dansk Biografisk Leksikon. 3. udg. Bd. I-XXVI. Red. af Svend Cedergreen Bech. 1979-84. København.

Dansk biografisk Haandleksikon. Red. af Povl Engelstoft. 1920-26. København.

Degn, Ole og Vagn Dybdahl (red.) 1968: Borgere i byens råd. Århus.

Dybdahl, Vagn 1959: Ejler Haugsted 1875-1959. Aarbøger for Aarhus Stift. Bd. 51, s. 7-17.

Eriksen, Palle 1990: Samsøs store stengrave. Ebeltoft. 
Ferdinand, Klaus 1999: Den etnografiske samling på Moesgård. I: Ole Høiris, Hans Jørgen Madsen, Torsten Madsen og Jens Vellev (red.): Menneskelivets mangfoldighed. Højbjerg, s. 33-46.

Forchhammer, Johs. 1866: Om oldnordiske Samlinger, historiske Museer o.s.v. navnlig i Jylland. Samlinger til Jydsk Historie og Topografi. Bind I, s. 48-65.

Fra Oldkammer til Forhistorisk Museum. 1986. Højbjerg.

Gejl, Ib (red.) 2000: Byens Borgere. Århus

Glob, P.V. 1970: Højfolket. København.

Haugsted, Ejler 1923: Udgravningerne paa Bispetorvet i Aarhus i Efteraaret 1921. Aarhus Stifts Aarbøger, s. 99-137.

Haugsted, Ejler 1929: Oldsagssamlingen i Aarhus Museum. Arosia. 8. årg. Nr. 2, s. 18-24.

Haugsted, Ejler 1935: Oldsager fra Nørrejylland i Aarhus Museums historiske Afdeling, indgaaede i Aarene 1932-34. Aarhus Stifts Aarboger, s. 137-159.

Haugsted, Ejler 1939: Runestene og Mønter. Aarhus gennem Tiderne. Bd. I. Århus, s. 69ff.

Haugsted, Ejler 1941: Kulturelle Institutioner. Aarhus gennem Tiderne. Bd. IV. Århus, s. 25765.

Holm, P. 1951: „Den gamle By« $i$ Aarhus. Århus.

Jensen, Jørgen 1988a: Christian Jürgensen Thomsen og treperiodesystemet. Aarbøger for Nordisk Oldkyndighed og Historie, s. 11-18.

Jensen, Jørgen 1988b: Sophus Müller og det moderne gennembrud i dansk arkæologi. Aage Andersen (red.): Festskrift til Olaf Olsen. København, s. 45-57.

Jensen, Jørgen 1992: Thomsens Museum. København.

Jensen, Jørgen 1993: Museernes Guldalder. Museum Europa, s. 77-89.

Jensen, Jørgen 2000: Museerne og folket. Søren Bitsch Christensen (red.): Grundlovens Danmark. Århus, s. 77-87.

Jeppesen, Jens 2001: Dalgas og oldtidsminderne. Skalk. 2001:4, s. 5-9.

Kjær, Birgitte 1980a: »Gamle Thomsens«børnebørn. Om oprettelsen af de første provinsmuseer i Danmark. Fortid og Nutid. Bd. XXVIII, hæfte 3, s. 362-89.

Kjær, Birgitte 1980b: Omkring oprettelsen af "Den historisk-antikvariske Samling i Aarhus» 1861. Arhus Stifts Årbøger, s. 43-75.

Kjær, Birgitte 1988: Gensidig afhængighed og godt samarbejde. Om C.J. Thomsens forhold til de kulturhistoriske provinssamlinger. Aarbøger for Nordisk Oldkyndighed og Historie, s. 187-96.

Kjærum, Poul 1999: Forhistorisk Museum 1949-1996. I: Ole Høiris, Hans Jørgen Madsen, Torsten Madsen og Jens Vellev (red.): Menneskelivets mangfoldighed. Højbjerg, s. 21-32.

Klindt-Jensen, Ole 1976: Moesgård. Højbjerg.

Larsen, Svend 1935: Et Provinsmuseums Historie. Odense Bys offentlige Samlinger. Odense.

Lassen, Thomas W. 1990: 90'ernes museum og tiden derfør. Lolland-Falsters Stiftsmuseums tidligste historie. Lolland-Falsters Stiftsmuseum. Årsskrift, s. 6-31.

Lundbæk, Dorrit 1967a: Et stykke af Aarhus Kunstmuseums historie. Aarhus Kunstmuseum, s. 15-44.

Lundbæk, Dorrit 1967b: Familien Weis og kunstlivet i Aarhus. Aarhus Kunstmuseum, s. 4782.

Løkkegaard, Søren 2002: Biblioteket på Moesgård. Højbjerg.

Mackeprang, Mouritz 1912: Nationalmuseet og Provindsmuseerne. Aarbøger for Nordisk Oldkyndighed og Historie, s. 157-64.

Magisterstaten 1962. København.

Mohr, Helga 1996: Brikker til Den gamle Bys tidligste historie - og kulturhistorien i Danmark. Den gamle By. Danmarks Købstadsmuseum, s. 115-25.

Museum Europa. Den jyske Historiker. Nr. 64.

Müller, Sophus 1897: Vor Oldtid. København. 
Müller, Sophus 1912: Nationalmuseet og Provindsmuseerne. Aarbøger for Nordisk Oldkyndighed og Historie, s. 164-188.

Nielsen, Flemming Steen: Bonden som museumsgenstand. Den jyske Historiker. Nr. 45, s. 7188.

Nielsen, Niels Løgager 1989: Afleveringspligt og udgravningsret. Fortid og Nutid. Bd. XXXVI. Hæfte 3, s. 194-203.

Nielsen, Niels Løgager 2001: Museer i oprør. Provinsmuseerne og Nationalmuseet i en brydningstid. Kuml, s. 111-158.

Poulsen, Karen Løkkegaard 2001: Oldsagssamlinger på danske herregårde. Kuml, s. 71-110.

Rasmussen, Holger 1979: Dansk museums historie. Hjørring.

Reeh, A. og G.V. Smith 1891: Nogle Grave fra Stenalderen. Aarbøger for Nordisk Oldkyndighed og Historie, s. 329-45.

Rubin, Marcus 1892: 1807-14. Studier til Københavns og Danmarks Historie. København.

Sagførere i Århus. 1956. Århus.

Sejr, Emanuel 1961-62: J.M. Mørk. Erhvervshistorisk Årbog. Bd. 13, s. 103-16.

Series Rectorum. Danske rektorer ved gymnasier og kurser siden Reformationen. Udg. Carl E. Jørgensen. 1967.

Skriver, Jens B. 2001: Moesgård. Historien om en herregård. Højbjerg.

Stensager, Anders Otto 2003: Arkæologen Vilhelm Christian Boye. Højfolkets protektor. Kuml, s. 111-156.

Street-Jensen, Jørn 1988: Thomsen og tredelingen - endnu engang. Aarbøger for Nordisk Oldkyndighed og Historie, s. 19-27.

Thomsen, Niels 1963: Daglivet og samfundet. I: Axel Steensberg (red.): Dagligliv i Danmark. Bd. 3. København, s. 633-61.

Thrane, Henrik 2000: Halvtreds års Forhistorisk Arkæologi ved Aarhus Universitet 19491999. I: Henrik Thrane og Søren H. Andersen: Arhusarkcoologi. Højbjerg, s. 7-51.

Wiell, Stine 1997: Flensborgsamlingen 1852-1864 - og dens skabne. Flensborg.

Wiell, Stine 2000: Kampen om oldtiden. Der Kampf um die Vorgeschichte. Aabenraa. 


\section{The Historical Museum in Århus}

The Age of Enlightenment resulted in museums coming into existence all over Europe. Their purpose was to preserve exceptional items for posterity and to promote knowledge associated with these items. The museum idea fused with the national movements current at that time.

In Århus a Society of History and Antiquities was formed in 1861. The purpose of the society was to promote knowledge of antiquities by creating a collection, and to inform the public about the past through presentations and lectures. The society was led by an honorary committee which was in charge of the scholarly work. The collection was housed in the town hall (fig. 3).

Over the years, the museum experienced fluctuations in its development as different people influenced its work. In the beginning, the cause met great support, but public interest was lost during the war with Germany in 1864, and interest was not re-established until later. The greatest scholarly authority of the museum, Edvard Erslev, left town, and others took over (fig. 2).

Around 1870, the museum thrived again under the strong influence of Vilhelm Boye, a former employee of the Old Nordic Museum in Copenhagen, who was able to impart great scholarly expertise to the Århus museum. When he moved away from the town, the museum languished again. Around this time, a large new museum was built. However, most of its space was taken up by the art collection, whereas the historical collection was limited to a box-room-like area in the attic (figs. 5 and 10).

Christian Kjær, a lawyer, came to the rescue. Although engaged in many other forms of business, he managed to make a constructive contribution to the running of the museum (fig. 6). He maintained good relations with the Old Nordic Museum - or the National Museum as it had been renamed - and he succeeded in raising a considerable government grant for a planned extension to the museum (fig. 7). At the same time, the society was changed into an independent institution under the supervision of the National Museum. The name was changed into The Historical Department of Århus Museum.

The scholarly work now secured higher priority, and the museum began to undertake archaeological excavations on a larger scale. The next persons to represent the museum were Captain Smith (fig. 8) and lawyer Reeh, who were both recognised for their professional skills.

By the early 1900s, the museum faced a dilemma: the funds were insufficient for working with anything but prehistory, but interest in recent cultural history had grown, and the need to include this in the museum work was pressing. The result was that $\mathrm{P}$. Holm (fig. 12) left the museum committee to found 'Den Gamle By, Danmarks Købstadsmuseum' (The Old Town, Denmark's Municipal Town Museum). In the 1920s the two museums began to cooperate, and the historical museum deposited its collections from the Middle Ages and later times in 'Den Gamle By'. Now the Historical Department of Århus Museum consisted of a prehistoric collection and a coin collection. Librarian Eiler Haugsted (fig. 13) headed the museum and improved the exhibition of the reduced collections.

Everyone agreed that the museum and the university would benefit from closer cooperation. The extensive collection of plaster casts of antique works of art was moved to the university's Department of Classical Archaeology and became the nucleus of its study collection. This resulted in much better space in the museum building. P. V. Glob was appointed Professor of Prehistoric Archaeology and leader of the museum. The engagement of a permanently employed, skilled leader 
resulted in marked changes in the museum, which now concentrated on Prehistoric Archaeology and Ethnography and soon achieved a special position within these fields. Within a few years - from being a museum run almost completely by volunteers - the museum had developed into a big institution with a large, professional staff.

Jens Skriver Moesgård Museum

Translated by Annette Lerche Trolle 